UNIVERSIDADE DE SÃO PAULO

ESCOLA DE EDUCAÇÃO FÍSICA E ESPORTE

\title{
A HISTÓRIA SOCIAL DO MOVIMENTO OLÍMPICO BRASILEIRO NO INÍCIO DO SÉCULO XX
}

Danilo Luis Rodrigues Lemos

SÃO PAULO

2008 
A HISTÓRIA SOCIAL DO MOVIMENTO OLÍMPICO BRASILEIRO NO INÍCIO DO SÉCULO XX

DANILO LUIS RODRIGUES LEMOS

Dissertação apresentada à Escola de Educação Física e Esporte da Universidade de São Paulo, como requisito parcial para obtenção do grau de Mestre em Educação Física. 


\section{AGRADECIMENTOS}

À Deus, que tornou tudo isso possível.

Aos meus Pais, Nicio e Palmira, que sempre acreditaram, mesmo quando eu fraquejava, por me ensinarem a não desistir, e por constituírem a pedra fundamental sob a qual a minha pessoa está edificada.

Aos meus irmãos, Nicio e Tani, pela alegria que carregam em seus corações.

À minha amiga/namorada/noiva/esposa Barbara, que tem no "aportuguesamento" de seu nome o adjetivo que melhor define suas características, pelo apoio, pelas palavras de carinho e por tornar agradáveis os momentos desagradáveis.

À docente livre e livre docente Katia Rubio, por acreditar nesse projeto desde os primórdios, pela sempre amável disponibilidade nos horários mais inóspitos, e por tornar fácil a difícil tarefa de concluir um mestrado.

À Ilza, Marcio e Lourdes pelo carinho e atenção com que tiraram minhas infinitas dúvidas, desde a inscrição para o processo de seleção até o depósito da dissertação.

Aos professores doutores Istvan Dobranszky e Emerson Franchini, membros da banca de qualificação, pelas preciosas críticas que engrandeceram esse trabalho.

Ao Club Athletico Paulistano, nas pessoas da Carol e da Rosa, pela generosidade de disponibilizar os materiais sob seus cuidados com tanta bondade.

À Biblioteca Nacional e ao Arquivo Histórico do Estado, por manterem viva a história desse país que carece de exemplos positivos; à Graça, do Depto. de Informações Documentais da Biblioteca Nacional, por agüentar todos os meus pedidos e tornar o meu prazo possível.

À D. Regina Bolonha, por me receber tão bem em sua casa durante as pesquisas no Rio de Janeiro.

Aos amigos da faculdade e do grupo de estudos pelas discussões acadêmicas, mas principalmente pelas não-acadêmicas. 
SUMÁRIO

Página

LISTA DE SIGLAS

RESUMO ii

ABSTRACT

1 INTRODUÇÃO 1

2 OBJETIVO 4

3 MÉTODO 4

4 JUSTIFICATIVA 6

$5 \quad$ REVISÃO DE LITERATURA 8

5.1 O Cenário Sócio Histórico 8

5.2 Origens do Esporte Moderno 10

5.3 Origens do Movimento Olímpico 30

5.4 Movimento Olímpico no Brasil 42

5.5 O Olimpismo Hoje 50

5.6 O Jornal Como Fonte 53

5.6.1 O Jornal do Brasil 54

6 RESULTADOS E DISCUSSÃO 56

6.1 A Formação do Comitê Olímpico Nacional 56

6.2 Decadência e Transição 69

6.3 A Formação do Comitê Olímpico Brasileiro 70

$7 \quad$ CONSIDERAÇÕES FINAIS 73

$8 \quad$ REFERÊNCIAS BIBLIOGRÁFICAS 77 


\section{LISTA DE SIGLAS}

ACB Automóvel Club do Brasil

ACM Associação Cristã de Moços

AEB Aero Club do Brasil

APEA Associação Paulista de Esportes Atléticos

CAP Club Athlético Paulistano

CBD Confederação Brasileira de Desportos

CBF Confederação Brasileira de Futrebol

CCE Centro de Cronistas Esportivos

$\mathrm{CCH}$ Comissão de Concursos Hípicos

COB Comitê Olímpico Brasileiro

COI Comitê Olímpico Internacional

CON Comitê Olímpico Nacional

COP Comitê Olímpico Português

CTB Confederação de Tiro Brasileiro

FBS Federação Brasileira de Sports

FBSR Federação Brasileira das Sociedades do Remo

FIFA Federação Internacional de Futebol

JB Jornal do Brasil

JO Jogos Olímpicos

LMEA Liga Metropolitana de Esportes Atléticos 
RESUMO

\title{
A HISTÓRIA SOCIAL DO MOVIMENTO OLÍMPICO BRASILEIRO NO INÍCIO DO SÉCULO XX
}

\author{
Autor: DANILO LUIS RODRIGUES LEMOS \\ Orientador: PROFA.DRA. KATIA RUBIO
}

A participação nos Jogos Olímpicos é condicionada à atuação de um comitê olímpico nacional. A criação dos referidos comitês é um fator controverso no Movimento Olímpico, uma vez que está subordinada à escolha de um representante nacional no Comitê Olímpico Internacional e que tal escolha não é democrática. Verificando a formação do esporte moderno e as características sociais que influenciaram a formação do Movimento Olímpico nacional e internacional, este trabalho visa identificar as razões que levaram o Brasil a fundar dois Comitês Olímpicos Brasileiros, e as implicações da história das entidades esportivas brasileiras nos dias de hoje. Para a realização do estudo foram consultados periódicos como o Jornal do Brasil, Jornal dos Sports, O Estado de São Paulo e Diário de São Paulo das décadas de 1910, 1920 e 1930 e também atas do Club Athletico Paulistano de 1912 a 1936, bem como o acervo da instituição. A agitação brasileira para ingresso no Movimento Olímpico inicia-se em 1912 e é influenciada pelo Comitê Olímpico Português e pelo caráter oligárquico do COI. A fundação do segundo COB em 1935 é marcada pela institucionalização das entidades esportivas e a conseqüente disputa pela representação das modalidades.

Palavras-chave: Esporte, Olimpismo, História, COB 


\begin{abstract}
THE SOCIAL HISTORY OF THE BRAZILIAN OLYMPIC MOVEMENT IN THE BEGINING OF THE XX CENTURY
\end{abstract}

\author{
Author: DANILO LUIS RODRIGUES LEMOS \\ Adviser: PROFA.DRA. KATIA RUBIO
}

The participation in the Olympic Games is conditioned to the existence of a National Olympic Committee. The creation of these committees is a controversial aspect in the Olympic Movement since it is subjected to the choice of a national delegate for the International Olympic Committee, and that this choice is not democratic. Investigating the modern sport formation and the social characteristics that have influenced national and international Olympic Movement foundations, this research aims to identify the reasons that led Brazil to create two Brazilian Olympic Committees, and the implications of the brazilian sportive organization history in the present days. The references for the study were newspapers such as "Jornal do Brasil", "Jornal dos Sports", "O Estado de São Paulo" and "Diário de São Paulo" from the 1910's, 1920's and 1930's, and the files and manager board acts from Club Athletico Paulistano. The brazilian progress trough the Olympic Movement starts in 1912 and received a major Portuguese influence by its Olympic members, and also by the oligarchic nature of the IOC. The second BOC foundation in 1935 is marked by brazilian sports institutionalization and the resulting disputes for different sports representation.

Keywords: Sport, Olympics, History, Brazilian Olympic Committee 


\section{INTRODUÇÃO}

O esporte surgiu na Inglaterra há menos de 200 anos e de lá se alastrou para os cinco continentes. Carregado com as influências do sistema político, econômico e social que o criou ele ganhou admiradores pelo mundo. Admiradores da estética e da plástica, admiradores da prática, e também admiradores do seu potencial, seja ele econômico, social ou político.

Atualmente ao redor dele se encontram números estrondosos. Milhões de praticantes, bilhões de espectadores e um sem número de reais, dólares e euros para financiá-los. Por tudo isso ele é considerado um dos maiores fenômenos da atualidade.

Sua forma de organização é similar à forma que existe hoje em empresas, sindicatos e até mesmo na administração pública. Os clubes ou agremiações são filiados a uma federação local, que é submissa a uma confederação regional que por sua vez se reporta a uma entidade nacional, a uma continental e por fim a uma única e mundial, formando assim um organograma de fácil compreensão.

Note que cada modalidade possui uma estrutura como essa, e que além dessas finitas mas numerosas instituições, existe ainda uma outra estrutura similar um pouco menor - pois já começa no âmbito nacional - para se responsabilizar pelo Movimento Olímpico e todas as suas implicações.

Sendo assim, uma vez que o objetivo de todas elas é divulgar, difundir e organizar a modalidade, este é sempre o ponto principal a ser alcançado, a fim de se obter seu desenvolvimento. No entanto, às vezes, essa meta é deixada de lado, fazendo com que a sobreposição dos objetivos pessoais sobre os anseios coletivos, gere a depreciação do esporte.

Não faltam na história recente do esporte casos de desavenças nas referidas instituições. As evidências são tantas que nos permite separar em problemas intra e extra 
instituições. Para o primeiro temos os extensos casos de brigas por posições hierárquicas reportados por JENNINGS \& SIMSON (1992) no Comitê Olímpico Internacional ou ainda o trabalho posterior de JENNINGS (2006) reportando as disputas desta vez na entidade maior do futebol, a FIFA.

Além destes, tivemos os episódios de descontentamento de atletas das federações de basquete, judô e tênis com seus respectivos representantes e a renúncia de toda a diretoria da federação brasileira de vela e motor por terem descoberto, logo após assumirem o cargo, que havia problemas administrativos pendentes.

No caso das brigas extra-instituições, tivemos, como conseqüência dos descontentamentos do basquete, a criação de uma outra liga para organizar a modalidade, o que culminou com batalhas na justiça e a ausência de um campeão brasileiro no ano de 2005 . No segundo semestre de 2007 a Liga Nacional de Futebol, que organiza as competições amadoras da modalidade, entrou em confronto com a respectiva confederação brasileira em virtude da organização do campeonato de futebol feminino.

Mas o caso mais intrigante, que chamou a atenção do autor e por isso é o foco dessa pesquisa, o que me fez interessar pelo tema, não é recente nem menos complicado. Aconteceu entre o Comitê Olímpico Nacional (CON) e o Comitê Olímpico Brasileiro (COB), instituições que representavam o mesmo objeto: a participação do Brasil nos Jogos Olímpicos.

De acordo com os poucos relatos sobre o tema, em 1914 foi formado no Rio de Janeiro o CON, na mesma assembléia, que contava com a presença de alguns representantes de instituições esportivas brasileiras, foi criada a Federação Brasileira de Sports, posteriormente chamada de Confederação Brasileira de Desportos (CBD) e hoje Confederação Brasileira de Futebol (CBF). 
Depois de mais de duas décadas, em 1935, também no Rio de Janeiro, sob o pretexto de se fundar na forma das leis olímpicas e em obediência a elas um Comitê Olímpico Brasileiro, fundou-se o COB. Visando não perder o espaço já conquistado no âmbito internacional durante os anos em que foi responsável pela organização das equipes que iam para os Jogos Olímpicos, a CBD cria um outro COB menos de duas semanas depois. FRANCESCHI NETO (1999).

O ápice dessa disputa se deu no ano seguinte, na décima edição dos jogos em Berlim, onde o Brasil foi representado por duas delegações, uma enviada por cada instituição. (RUBIO, 2006).

De extrema importância nesse contexto, são as atitudes do Comitê Olímpico Internacional com relação à inclusão de novos delegados no COI.

Por ser ainda uma instituição em fase embrionária - ou conforme a periodização sugerida por RUBIO (2006), estando em sua fase de estabelecimento - o Comitê buscava se fortalecer através de laços políticos, como comprova a carta de Raul de Rio Branco aos brasileiros ligados aos esportes. Entretanto, tal prática é incongruente com os postulados olímpicos, redigidos pelo próprio Coubertin, que afirmam a condição apolítica e apartidária da entidade.

E é nessa diferença entre atos e palavras que se fortalece entre as instituições esportivas a discórdia com relação à criação dos COB.

Entendendo que essas divergências põem de lado o objetivo maior das instituições e prejudicam tanto as modalidades em si quanto a confiança dos que a acompanham naqueles que a gerenciam, este trabalho visa buscar na história do esporte e da formação destas instituições, as causas desse tipo de ocorrência. 


\section{OBJETIVO}

O objetivo principal deste trabalho é levantar informações que tornem possível verificar as razões da criação de um Comitê Olímpico Nacional quando outro semelhante e com as mesmas funções já existia e também se existem semelhanças entre o COB formado em 1914 e o COB formado em 1935.

Para tanto foi necessário buscar novos elementos que auxiliassem na compreensão dos fatos e eventos que deflagraram a participação brasileira no Movimento Olímpico, além de analisar as relações institucionais no esporte que culminaram com a entrada e consolidação do Brasil no Movimento Olímpico internacional.

E assim, através dos estudos da história, compreender melhor o presente momento das instituições que comandam o esporte brasileiro para ser possível aprimorar o seu futuro.

\section{MÉTODO}

O presente estudo tem por meta a análise de fontes primárias de informação, como jornais e periódicos da época bem como documentos das instituições participantes do processo histórico, como as atas das reuniões de instituições e agremiações políticas e esportivas.

Conforme as idéias propostas por CARDOSO \& BRIGNOLI (2002) o eixo das preocupações do historiador é o homem e a sua atividade, reafirmando assim a necessidade de se buscar um denominador comum entre a história da civilização material e a história da mentalidade coletiva.

Nesse contexto ELIAS (1970) explica que a sociologia consiste em dar conta das evoluções de longa duração, que permitem compreender as realidades do presente. Apesar de 
ter um objeto histórico por se situar no passado, sua perspectiva em nada é histórica, uma vez que não se prende com indivíduos, supostos como livres e únicos, mas com as posições que existem independentemente deles e com as dependências que regulam o exercício de sua liberdade.

Desta maneira, este trabalho busca relacionar os atores sociais com a realidade que os envolvia e conseqüentemente melhor compreender o como e o por quê das atitudes por eles tomadas, idéia que vai de encontro às características de uma pesquisa histórica analítica segundo STRUNA (2002).

Foram pesquisadas todas as atas de diretoria do Club Atlético Paulistano de 1912 a 1936, além de todo acervo referente a Jogos Olímpicos e futebol do Centro Pró-Memória da referida instituição, nos meses de janeiro e março de 2008.

Foi feito contato com o setor de acervo do Fluminense Football Club que alegou, segundo o seu responsável, não obter nenhum documento relativo à participação de Arnaldo Guinle, presidente do clube na época, no Comitê Olímpico Brasileiro e Internacional. Também se buscou os documentos da CBF, e a informação recebida foi a de que em virtude da ausência de espaço na sede provisória, os documentos foram todos encaixotados e depositados no centro de treinamento da entidade em Teresópolis-RJ.

Em função da condição de Ministro Brasileiro no exterior de Raul do Rio Branco, um dos principais protagonistas desta pesquisa, houve ainda a tentativa de se pesquisar os documentos do Arquivo Histórico do Itamaraty na cidade do Rio de Janeiro, o qual também não foi possível devido a uma higienização do acervo que impediria visitas durante todo o primeiro semestre de 2008 . 
As pesquisas de jornais foram feitas no Arquivo do Estado de São Paulo entre novembro de 2007 e janeiro de 2008, e envolveram o acervo de publicações de 1914 e os jornais “O Estado de São Paulo" e "Diário de São Paulo" de 1934 a 1936.

Em função da pouca quantidade de informações referentes principalmente à segunda década do século XX, e da menção de fontes cariocas, a pesquisa também foi realizada no acervo da Fundação Biblioteca Nacional, em abril de 2008 e abrangeu todos os exemplares do “Jornal do Brasil” de novembro de 1912 a julho de 1914, todas as páginas esportivas do referido periódico de outubro de 1932 a outubro de 1936 e todos os exemplares do Jornal dos Sports, de 1934 a 1936.

A base das informações aqui contidas foi retirada de exemplares do Jornal do Brasil (JB) em função da qualidade das informações nele contidas com relação a outros periódicos. Coincidentemente, relacionando o desenvolvimento da pesquisa com as referências bibliográficas e fazendo a análise crítica minuciosa, descobriu-se que os mantenedores do periódico carioca estavam envolvidos na criação do $\mathrm{CON}$, sendo um deles o seu primeiro presidente.

Em função da criação de três comitês olímpicos no Brasil, para facilitar a compreensão do texto, será denominado de Comitê Olímpico Nacional o comitê fundado em 1914 e de Comitê Olímpico Brasileiro as organizações fundadas em 1935, sendo que o complemento denomina se foi fundado pela CBD ou pelos delegados brasileiros.

\section{JUSTIFICATIVA}

Os Jogos Olímpicos são a maior manifestação esportiva do planeta, no entanto a maior parte das publicações a respeito dos Jogos fica a cargo de cronistas e jornalistas que tratam o 
objeto de maneira distinta da acadêmica, proporcionando à academia novos horizontes de um campo que ainda pode ser muito explorado. A história do Movimento Olímpico Brasileiro está entre estes campos e possibilita o estudo de diversos fatores como, no caso deste trabalho, a sua própria origem.

Sobre o estudo da história, faço uso das palavras de SCHAFF (1991):

"Reescrevemos continuamente a história porque os critérios de avaliação dos acontecimentos passados variam no tempo e que, por conseqüência, a percepção e a seleção dos fatos históricos mudam, para modificar a própria imagem da história.” (Pág 272).

Assim vejo a justificativa para a realização deste trabalho baseada na busca de uma nova interpretação e também na descoberta de novos fatos que possam auxiliar na compreensão do presente e na melhoria do futuro, promovendo um desenvolvimento coerente, capaz de evitar espaços por onde penetrem a sobreposição de interesses pessoais sobre os coletivos e, principalmente, a destruição/desmoralização do esporte.

De outra maneira, fatos ainda pouco elucidados como a apropriação pela Confederação Brasileira de Desportos (CBD) das obrigações do Comitê Olímpico Nacional (CON) e a criação de um outro comitê, desta vez com o nome de Comitê Olímpico Brasileiro (COB), 21 anos após a criação do CON justificam uma investigação mais profunda das relações entre as instituições esportivas da época, bem como da biografia de seus representantes, a fim de poder encontrar novas respostas para essas questões e melhor compreender as instituições esportivas nos dias de hoje. 


\section{REVISÃO DE LITERATURA}

\subsection{O CENÁRIO SÓCIO-HISTÓRICO}

Descoberto e colonizado por Portugal, o Brasil, além de ter como língua oficial a língua dos colonizadores, carrega outros milhares de costumes "herdados" da influência lusitana na história brasileira. No entanto, o país foi também influenciado por diversas outras culturas de imigrantes que aqui se instalaram nos diversos momentos da história. Hoje o Brasil saboreia a pizza italiana, o dendê dos pratos africanos, o peixe cru japonês, pratica a "ciesta" espanhola quando possível, e realiza diversos outros hábitos adquiridos ao longo do tempo. Uma dessas influências que além de ter deixado raízes ainda exerceu grande alcance no território nacional foi a influência inglesa.

Baseada principalmente na economia, as relações entre Portugal e Inglaterra se intensificaram muito durante o desenvolvimento da história do Brasil, principalmente no final do séc. XVIII e início do séc. XIX quando ocorre naquele país a revolução industrial. Segundo FAUSTO (1995), tal período fez com que o Reino Unido impusesse ao mundo o livre comércio e o abandono dos princípios mercantilistas ao mesmo tempo em que protegia seu mercado e o de suas colônias com tarifas protecionistas. Além disso, através de acordos, alianças, e até mesmo contrabando, penetravam cada vez mais nos sistemas coloniais da América luso-espanhola. No Brasil desse período, por exemplo, surgiam as idéias inglesas de acabar com o tráfico de escravos.

A guerra de Napoleão contra a Inglaterra foi fundamental no aumento da influência inglesa sobre Portugal e conseqüentemente sobre suas colônias. A proximidade de uma invasão francesa fez com que o príncipe regente português, Dom João, decidisse pela 
transferência da corte para o Brasil, e a escolta dos cerca de 10 a 15 mil viajantes portugueses foi feita pela marinha inglesa. Aqui chegando, Dom João decretou a abertura dos portos às nações amigas, leia-se Inglaterra. Sobre esse fato FAUSTO (1995) coloca que era preferível legalizar o extenso contrabando existente entre a Colônia e a Inglaterra para assim receber os impostos devidos.

Assim, o Brasil passava a ser mais um mercado consumidor para os produtos ingleses. Aos outros países produtores, as taxas comerciais inviabilizavam a disputa. À corte poucas opções restavam, pois dependia do resultado da guerra entre França e Inglaterra para reaver a metrópole e da marinha inglesa para proteger suas colônias.

Em 1825, pouco depois da independência, o Brasil contrai seu primeiro empréstimo externo, da Inglaterra por sinal, compensando Portugal pela "perda" da posse da colônia. A influência inglesa, que já era presente, passa a ser imprescindível.

No final do séc. XIX o Brasil era um Império colonial e a economia brasileira dividiase em dois grandes blocos: um era composto pela agricultura de café, algodão e cana de açúcar, nas regiões nordeste e centro-sul, e pela extração da borracha na região amazônica, ambas destinadas à exportação; O outro era destinado ao consumo interno, predominava nas regiões de Minas Gerais e Rio Grande do Sul e tinha na criação de animais e na plantação de alimentos o seu grande produto.

Os maiores clientes da produção brasileira eram Inglaterra e EUA, respectivamente. E o saldo positivo na balança comercial, quando existia, era voltado para pagamento da divida externa, contraída junto aos mesmos compradores.

Com a proclamação da república em 1889, a economia pouco se modificava, já a situação política sofria grandes transformações. De acordo com a primeira constituição, o Brasil adotaria o sistema de república federativa liberal, dando liberdade aos Estados da 
federação para exercer atribuições diversas, como fazer empréstimos no exterior e organizar forças militares próprias. (FAUSTO, 1995). Na prática, era um ambiente voltado para as oligarquias dos estados mais representativos.

Esse período republicano que se estende até 1930, foi marcado politicamente pelo predomínio dos estados de São Paulo e Minas Gerais, na denominada política do café com leite.

No plano financeiro a situação agravou-se. A herança de pagamento da divida externa deixada pelos sistemas anteriores tornou-se mais amarga e juntou-se a um aumento do déficit público. A saída encontrada pelo governo foi realizar um empréstimo de consolidação da dívida, também conhecido como funding loan.

Por esse acordo o país garantia, através de um novo crédito, o pagamento dos juros e do montante dos empréstimos anteriores. Em troca dava a garantia das rendas alfandegárias do Rio de Janeiro; ficava proibido de contrair novos empréstimos por 3 anos, e comprometia-se a incinerar papel-moeda para reduzir a inflação.

De um modo geral, e acompanhando as modificações mundiais, a Primeira República caracterizou-se pelo inicio da urbanização em função da também recente industrialização. Os maiores empréstimos e investimentos provinham ainda da Grã-Bretanha, nas companhias de seguros, empresas de navegação, bancos e empresas geradoras e distribuidoras de energia. (VÁRIOS AUTORES, 1991).

Tal participação durou ainda muitos anos, adentrando ao século XX, e não se restringiu apenas aos assuntos econômicos. A imigração de muitos ingleses para o Brasil fez com que eles trouxessem mais do que o dinheiro, com eles vinham também seus costumes e suas tradições. À partir das companhias industriais inglesas e das empresas e empreendedores, 
chegavam ao país também as normas de conduta e com elas da prática de modalidades esportivas tais como são praticadas contemporaneamente.

Passemos agora então a compreender como e por que o esporte moderno se formou na Inglaterra e as repercussões de sua chegada e disseminação em solo brasileiro.

\subsection{ORIGENS DO ESPORTE MODERNO}

As práticas corporais competitivas institucionalizadas, também denominadas de esporte, derivam das atividades corporais não competitivas ou não institucionalizadas realizadas ao longo do processo histórico dos homens na Terra. Foi através dos jogos e brincadeiras característicos de cada cultura que a prática esportiva ganhou forma e se tornou o que é hoje.

HUIZINGA (1971) define o jogo como um elemento que antecede à cultura, pois cultura pressupõe sociedade humana e, no entanto os animais já brincavam antes dos primeiros registros históricos da civilização.

BARBANTI (2003) e HELAL (1990) conceituam o esporte baseando-se nas conceituações de brincadeira e jogo. A primeira seria então qualquer atividade sem regras fixas; o segundo seria definido pela presença e aceitação pelos praticantes das regras que definem essa atividade. Como resultado da conceituação de jogo, temos o jogo nãocompetitivo e o jogo competitivo. E é justamente este último que precede o conceito de esporte moderno, descrito como:

"qualquer competição que inclua uma medida importante de habilidade física e esteja subordinada a uma organização mais ampla 
que escape ao controle daqueles que participam ativamente...da ação" (HELAL, 1990, Pág 24).

A definição de BROHM (1982) é similar, mas por ser mais detalhada servirá de base para essa análise inicial. Segundo esse autor, o esporte é:

“...um sistema institucionalizado de práticas competitivas, com predomínio do aspecto físico; delimitadas, reguladas, codificadas e regulamentadas convencionalmente, cujo objetivo confesso é, sobre a base de uma comparação de provas, de marcas, de demonstrações, de contribuição física, designar o melhor concorrente (o campeão) ou de registrar a melhor atuação (recorde).” (Pág. 42)

GUTTMANN (1978) discorre sobre o esporte moderno relacionando-o às práticas da antiguidade em sete aspectos a saber: Secularização - esportes modernos são profanos enquanto os antigos eram mais ligados à religião; Igualdade - a desigualdade dos embates modernos é usada para explicar a desigualdade em outras áreas; Especialização - o esporte moderno é especializado diferentemente das práticas antigas; Racionalização - os jogos modernos são racionalizados seguindo a relação lógica entre os meios e os fins, e as regras são culturais e não instruções divinas; Organização Burocrática - objetiva verificar se as regras são universais e facilitar a rede de competições do contexto local para o global; Quantificação - em virtude da especialização e da racionalização faz-se necessário aprimorar os modos de quantificar os pontos marcados ou as distâncias e velocidades a serem batidas; Busca por Recordes - conseqüência da quantificação. 
GARRIGOU (2001) também compara o esporte moderno com o antigo. De acordo com ele, a forma atual diferencia-se da ancestral principalmente pela sensível diminuição do nível de violência.

Diversos autores concordam que o esporte moderno, tal como é praticado nos dias de hoje é proveniente da Inglaterra (BETTI, 1991; BRACHT, 1997; BROHM, 1982; ELIAS, 1992; GONZÁLEZ, 1993; MANDELL, 1986; McINTOSH, 1975; RUBIO, 2006; SALVADOR, 2004), no entanto, o processo que levou a essa forma de esporte é explicado de formas diferentes. Tais explicações não são excludentes e dão ênfase a diferentes modos de observação do mesmo fenômeno e conseqüentemente de seu desenvolvimento.

GONZÁLEZ (1993) afirma que o esporte surgiu da consciência burguesa de controlar a população para assegurar a produtividade, e foi com os filhos dessa burguesia que se deu a regulamentação das práticas corporais.

As public schools eram os centros educativos, ou internatos, aos quais a aristocracia e a alta burguesia encaminhavam seus filhos. Ao contrário do nome eram bem pagas e extremamente rígidas, sendo destinada, exclusivamente, aos filhos homens.

De acordo com essas instituições e com os ideais aristocráticos, era importante propiciar aos futuros líderes sociais, um tempo livre para a formação do seu espírito de independência. Porém, diante da rigidez das aulas e das tediosas sessões de aprendizado, os momentos de folga eram preenchidos por atos de vandalismo, invasões de propriedade e práticas populares, sendo que, os menores e mais novos eram sempre perseguidos. Assim, as instituições foram obrigadas a rever o princípio da liberdade.

A esse problema somava-se ainda a necessidade de reforma dos conceitos dessas instituições, resultado da crescente inversão das idéias sobre a educação das classes ascendentes ao longo do século XIX. 
Interessante ressaltar que algumas das práticas do tempo livre desses alunos consistiam em práticas populares de jogos, inclusive com bola, mas que não eram bem vistas por serem violentas e não possuíam ainda a regulamentação que as tornaria esporte por definição.

Com o intuito de modificar essa prática do tempo livre e manter os alunos dentro dos seus muros, algumas das escolas passaram a incentivar a prática corporal dentro dos seus domínios e para isso oficializaram e regulamentaram, juntamente com seus alunos, as formas de jogo e as técnicas corporais que deveriam ser permitidas ou proibidas.

Não foi sem resistência que os alunos aceitaram substituir o tempo livre pelos jogos sob vigilância dentro da escola. Diversas revoluções ocorreram antes que se houvesse a assumpção do sentimento de participação e de identidade para com as respectivas escolas e o gosto pela prática dentro da mesma. Alguns desses desentendimentos precisaram até de intervenção militar. E ainda sim os estudantes conseguiram manter sua autonomia em relação ao tempo livre, o que potencializava a estrutura hierárquica baseada na tradição dos veteranos.

RUBIO (2006) informa ainda que esse processo de regulação a que foram submetidos os passatempos tradicionais até serem transformados em esportes, foram produto de assembléias de cursos e escolas, de discussões entre os estudantes relativas às técnicas corporais que deveriam ser permitidas e proibidas.

Para DUNNING (2001) as public schools eram um tipo de escola que, de maneira especificamente inglesa, dispunha de alto grau de independência em relação ao estado. Esse alto grau relativo de autonomia facilitou a inovação no seio destas instituições, e isso, somado a um clima agudo de tensão e de competição entre elas, foi uma das condições de esportização do futebol - processo durante o qual o futebol e o rugby começaram a emergir como esportes modernos. 
Um dos expoentes nesse processo foi Thomas Arnold, diretor da Escola de Rugby, situada a noroeste de Londres, de 1828 a 1842. Segundo McINTOSH (1975) Arnold suprimiu a ilegalidade e também as perseguições à caça no campo e outros esportes campestres. Assim os estudantes voltaram-se cada vez mais para os desportos permitidos. Além disso, o diretor buscava fazer com que o colégio fosse dirigido pelos próprios alunos e via no esporte a preparação ideal para atingir esse objetivo.

Segundo SALVADOR (2004), as práticas esportivas representavam para Arnold, ainda que em menor escala, a sociedade em que estavam incluídos. As relações e hábitos adquiridos na prática dos esportes seriam assim o melhor treinamento para o cumprimento das obrigações advindas da vida social. Ao sair da escola para adentrar à sociedade, os alunos tenderiam, como no esporte, a ser não espectadores mas atores preparados e destacados nas relações de convivência, na competição social, no respeito a seus iguais e no cumprimento das regras estabelecidas.

Uma outra qualidade da idéia do diretor de Rugby era a de deixar a cargo dos alunos o máximo possível de assuntos relacionados ao esporte. Assim, os alunos se responsabilizariam pelas mudanças na modalidade, pelos métodos de treinamento, pela direção das organizações, pela administração dos recursos obtidos, ou seja, estava preparando as bases dos futuros clubes. Para Arnold:

"Uma associação desportiva é uma pequena sociedade, e uma equipe de futebol é um pequeno exército. ” (McINTOSH, 1975. Pág. 89) 
O uso do termo "exército", alude tanto ao respeito à hierarquia quanto à manifesta intenção de preparação dos gentlemen a serviço do rei e de suas instituições para a formação e consolidação do império britânico.

A conseqüência das idéias de Arnold vai além ao se pensar que a manifesta intenção de preparação dos gentlemen a serviço do rei e de suas instituições fortaleceu a formação do império britânico.

Já McINTOSH (1975) afirma que apesar de ser atribuído a Arnold o desenvolvimento do culto aos jogos, os estudantes já organizavam seus jogos, mesmo desafiando as autoridades. O que o diretor de Rugby fez foi acelerar um movimento que já havia começado.

Findo o processo de discussões entre alunos e professores/diretores e iniciada a prática esportiva - tida também como valor educativo - e aceita a proposta de Arnold, o esporte se transformou na parte central do currículo escolar. Assim, o sucesso obtido em Rugby foi divulgado entre outros diretores e passou a ser implantado nas demais escolas inglesas e delas para a sociedade.

Na passagem das public schools para a sociedade, o esporte contou ainda com o apoio da igreja que não apreciava as práticas populares, mas não as substituía por não possuir alternativas para dar subsídio à mudança, e é nesta conjunção que ela conhece e passa a difundir o esporte. McINTOSH (1975), afirma ainda que:

"a promoção do desporto, levada a cabo pelas igrejas e pelos seus membros, estava em relação direta com o desenvolvimento econômico da comunidade e com o aumento das horas de lazer”. (Pág 97). 
Mas isso nem sempre foi assim, pois foi a mesma igreja, ao condenar práticas recreativas no domingo, que impediu o desenvolvimento do esporte entre os habitantes das principais cidades inglesas. O progresso social e econômico, que deu meio dia de sábado para os trabalhadores é que auxiliou nesse crescimento das práticas corporais.

Uma segunda explicação sobre o surgimento do esporte é dada por BROHM (1982), que em seus estudos sobre o desenvolvimento do esporte moderno o descreve como conseqüência da sociedade industrial inglesa.

Segundo este autor, a partir do século XVIII a aristocracia fomenta as práticas populares através de incentivos e recompensas, chegando mesmo a praticar, porém sem se misturar ao povo.

Através do sistema de apostas, os britânicos financiavam a prática esportiva. Tais práticas podiam estar ligadas às corridas de cavalo, às corridas a pé ou mesmo às lutas de boxe e esgrima. As apostas deixam, assim, de ser ligadas ao jogo de azar e passam a incentivar a proeza física.

Desse processo e em virtude de se definir regras claras para o desafio, desenvolveramse paralelamente as formas de medição tanto de tempo como de distância, o que leva BROHM (1982) a destacar três características essenciais do esporte moderno: "a perseguição do recorde, o crescente interesse pela velocidade e a obsessão pelo mensurável”.

MANDELL (1986) complementa essa informação afirmando que o recorde desportivo pressupõe uma nítida apreciação do êxito quantificável e, necessariamente, da medição exata do tempo e espaço, aludindo assim a outras novidades que apareceram primeiro e mais claramente na Inglaterra. Esta difundida tendência à quantificação do tempo, adverte a existência de um pré-requisito real para a produção industrial disciplinada. 
Sobre o sistema de apostas, tem-se o desafiante e o desafiado, ou seja, existe uma competição entre, pelo menos duas pessoas, e pode-se inferir, que tal prática não é exclusividade de adultos ou de aristocratas, pois pode ser realizada por duas crianças em qualquer embate. MANDELL (1986) afirma que as apostas não eram novidade na história mundial, sendo praticadas anteriormente por gregos, egípcios, romanos e indígenas americanos. No entanto, o sistema de apostas inglês é algo sem precedentes na história, e está distante da idéia de azar ou de confiança no destino. Segundo esse novo modo de jogar - do inglês "to gamble" - acreditava-se que o conhecimento a respeito dos cavalos ou dos corredores, proporcionava informações mais objetivas e, por conseguinte, superiores às dos apostadores rivais, aumentando assim a chance de êxito.

Existem ainda outras características desse sistema de apostas passíveis de considerações. Primeiro a possibilidade de uma única disputa incluir diversos participantes que apóiam ou ao desafiante ou ao desafiado, assim as disputas deixam de ser entre duas pessoas e podem se expandir para agremiações ou até mesmo cidades. De maneira análoga, em uma segunda característica, é possível que um único indivíduo desafie vários outros ou várias instituições ao mesmo tempo. E por último, o desafio pode ser em relação ao tempo ou à distância a ser percorrida e não mais a uma pessoa, o que desobriga a existência de um combatente/desafiante humano por parte daqueles que duvidam da realização da proeza.

MCINTOSH (1975) enriquece essas informações dissertando sobre a importância das apostas e da aristocracia para a sobrevivência do esporte. Segundo ele haviam modalidades, tais como o cricket e o golfe, que não eram exclusivamente aristocráticas mas não atraíam uma grande quantidade de jogadores ou espectadores.

Os esportes que seduziam a multidão eram as corridas de cavalos, os jogos de soco por dinheiro e as proezas pedestres de andar ou correr. Coincidentemente, todas elas eram de fácil 
assimilação das regras e também, talvez mesmo em função desse dinâmico conhecimento das regras, fáceis de se organizar as apostas.

Com o passar do tempo, e por envolver grandes somas de dinheiro, essas modalidades começam a perder o prestigio em função dos casos de corrupção e compra de resultados, desfazendo assim a crença dos espectadores-apostadores no seu conhecimento e levando a aristocracia a desconsiderar tais competições como digna deles, quer como competidores quer como espectadores.

Em função disso, os gentlemen fundam associações só para eles, de maneira a poderem recomeçar as práticas atléticas sem qualquer dos abusos já habituais em outras modalidades. Não por acaso, as modalidades começam a perecer e as sobreviventes eram somente aquelas patrocinadas pela aristocracia, que transformou suas reuniões em organizações que estavam prontas a estabelecer a lei e fazer com que essa lei fosse cumprida.

"Onde quer que a aristocracia não se organizasse num clube
controlador..., não conseguia...impor respeito e dominar os elementos
grosseiros e inescrupulosos, e assim os desportos morriam." (McINTOSH, 1975, Pág 85)

ELIAS (1992) apresenta uma outra explicação sobre o desenvolvimento do esporte moderno, e que contempla um outro fator também decorrente das idéias burguesas na formação do esporte: a presença das normas sociais de conduta. Além disso, seu trabalho se baseia nas características sócio-histórico-geopolíticas daquela sociedade para explicar o porquê de ser ali o berço do esporte contemporâneo. Para Elias, a relação entre o 
desenvolvimento do esporte e da estrutura de poder na sociedade inglesa explica o motivo de o esporte ter se desenvolvido primeiro na Inglaterra.

Segundo sua teoria, a modificação e regulamentação das normas de conduta entre as classes mais altas eliminou os excessos de auto-castigo e auto-indulgência. A esse novo modo de conduta chamou-se de civismo, originando posteriormente o verbo civilizar. Existe uma relação dessa mudança com os processos de formação dos Estados e os agrupamentos de nobres. O esporte se desenvolveu na mesma direção. A esse processo o autor deu o nome de processo civilizador

Em virtude desse processo civilizador, o sistema parlamentarista passou a evitar os conflitos físicos, logo, os representantes da política se viram obrigados a desenvolver outras habilidades para vencer as discussões, exigindo assim maior esforço na busca e prática dessas habilidades.

Tal esforço gerou uma mudança na sociedade, o que ocasionou uma mudança nos passatempos desse grupo, com a imposição de uma maior tolerância ao outro.

Essa tolerância nos passatempos permitiu maior proteção aos atletas e também a formação de regras definidas para regular a prática - esses dois fatores auxiliam a compreender o porquê da grande aceitação dessa prática em outros países.

Desse processo, conclui-se que o surgimento do esporte foi parte integrante da pacificação das classes altas da Inglaterra. (ELIAS, 1978; 1992)

GARRIGOU (2001) e DUNNING (1990) corroboram o pensamento de Elias asseverando a relação entre o processo civilizador e o desenvolvimento do esporte.

Tal tese é complementada por SALVADOR (2004), ao afirmar que o esporte se codificava e humanizava por meio de regulamentos da mesma maneira que se observava na sociedade inglesa uma tendência à codificação e à racionalização das leis e formas de 
governar. Para BOURDIEU (1990), codificar significa colocar na devida forma e dar forma. Ademais, a codificação está intimamente ligada à disciplina e à normalização das práticas.

MANDELL (1986) auxilia fornecendo informações sobre a Inglaterra que possibilitaram esse desenvolvimento rumo à pacificação.

O fato de ser uma ilha diminuía o medo das invasões e propiciava cidades sem muros e com um sistema de transporte inter-regional aberto, desse modo, a convivência entre classes altas e baixas da sociedade não era isolada, permitindo alguma mobilidade social. As escolas da aristocracia eram acessíveis aos endinheirados. O status aristocrático dependia mais da riqueza e da influência na corte do que dos antepassados fidalgos. A classe dos trabalhadores gozava de uma vida melhor do que seus homólogos continentais, pois diferentemente daqueles, estes podiam ler livros, ir ao teatro e participar de diversões "esportivas" com mais regularidade.

Ainda segundo este autor, a vida moderna exigia a sublimação da agressividade.

FRANCO JR (2007) segue na mesma linha, entretanto, e falando exclusivamente do futebol, relaciona o surgimento da modalidade à Revolução Industrial. Para ele, os dois fenômenos baseiam-se em competição, produtividade, secularização, igualdade de chances, supremacia do mais hábil, especialização de funções, quantificação de resultados e fixação de regras. Características que nos remetem ao trabalho de Guttmann (opt. cit.)

Novamente SALVADOR (2004) corrobora essas idéias ao afirmar que em função da formação precoce do estado inglês, o esporte pode se desenvolver, ao contrário, por exemplo, do "Calcio" italiano que não se desenvolveu por não haver uma unidade naquela região.

ELIAS (1992) acrescenta outro fator que auxiliou no desenvolvimento do esporte na ilha: o bom relacionamento entre a nobreza cortesã e a nobreza rural. Se comparada à França, por exemplo, onde havia uma grande divisão entre as duas nobrezas, na Inglaterra, por um 
equilíbrio diferente de poderes, ambas compartilhavam momentos juntas, possibilitando à nobreza rural desfrutar da vida urbana e à nobreza da corte da vida no campo, facilitando assim a prática de jogos ao ar livre como o cricket.

Ainda fazendo uso da comparação com a França para melhor compreender a gênese do esporte na Inglaterra, o autor afirma que, no país continental, em virtude da monarquia aristocrática, a reunião de pessoas em forma de associação era restringida. Já na porção insular não havia tal restrição, favorecendo assim a formação de associações e clubes. Eram nesses clubes que ocorriam as discussões e uniformizações das regras. Numa etapa seguinte, quando da realização de jogos entre cidades, essas uniformizações se disseminavam e assim cresciam as modalidades.

Sobre a participação da sociedade aristocrática no esporte, SALVADOR (2004) afirma que o esporte nasceu da ociosidade dos integrantes dessa classe. Segundo ele, quando a burguesia emerge e assume a dominação do estado, a ociosidade dos nobres aumenta e eles se vêem desligados de suas principais atividades. As leis promulgadas após a revolução parlamentarista distanciaram ainda mais a aristocracia de toda atividade produtiva. Para esse autor o esporte inglês é a evolução de seus jogos rurais.

Uma contribuição importante de ELIAS (1992) se encontra na informação de que com o processo civilizador, dois grupos de classe alta, que antes se tratavam com violência, transformaram-se em partidos de classe alta respaldados por um pequeno eleitorado e se enfrentavam com métodos que não eram violentos em termos gerais, mas não excluíam o suborno e a compra de votos.

De posse desses dados é possível inferir que o processo civilizador não excluiu as maneiras ilícitas de buscar a vitória nas eleições, e assim, o que já era uma prática comum no 
setor político passou a ser utilizado também no setor esportivo, gerando diversas resoluções para evitar no esporte esse tipo de atitude.

Essa afirmação corrobora o que foi colocado há pouco sobre a corrupção em algumas modalidades envolvendo apostas e as respectivas reações tanto para a modalidade quanto para a aristocracia.

Sobre as organizações esportivas, McINTOSH (1975) afirma que desde o início do século XIX a aristocracia britânica já apreciava a prática de exercícios físicos ao ar livre, e os próprios aristocratas patrocinavam seus jogos. Desde então já existiam as referidas organizações, tais como o Marylebone Cricket Club e o Royal and Ancient Golfe Club, porém o objetivo das mesmas não era dirigir ou organizar os respectivos desportos, mas se baseava no prestígio de seus membros, que eram convocados para arbitrar as disputas ou para determinar acordos sobre regras de jogo ou etiqueta. Já organizados, com a difusão das modalidades, essas entidades passam gradualmente a assumir o controle.

De acordo com ELIAS (1992), o acordo sobre as regras nesse nível de integração e as modificações caso as mesmas não satisfizessem as condições do jogo foi uma condição primária para transformar um passatempo tradicional em esporte. MANDELL (1986) acrescenta ainda o desenvolvimento simultâneo das estradas de ferro, que permitiam o deslocamento mais ágil de atletas e espectadores; e também dos periódicos, que informavam tanto sobre os eventos passados como sobre as perspectivas dos próximos encontros, para justificar o momento dessa mudança dos passatempos.

Como conseqüência dessa transformação, Mandell afirma que o esporte não apenas facilitou, mas também estimulou a adaptação mental de toda a população à demanda do mundo moderno. $\mathrm{O}$ esporte inglês refletia e reforçava os conceitos fundamentais do mundo industrial necessários para manter um mínimo de coesão social. Na visão de SALVADOR 
(2004), o esporte facilitou e ajudou a entender a filosofia do capitalismo, pois apenas os mais preparados e os que contam com mais recursos vencem, aos demais cabe se conformar com a derrota; além de auxiliar a compreender o efêmero de ganhar e perder.

ELIAS (1992) ressalta ainda a importância de não se poder aplicar uma relação causal entre o esporte e o sistema parlamentarista, ou que um é efeito do outro. Ambos tipificavam a mesma mudança na estrutura de poder e nos hábitos sociais ingleses da classe que emergiu como grupo detentor do poder.

GONZALEZ (1993) complementa essa idéia afirmando que é um erro considerar a "invenção - ensino / imposição" das práticas esportivas como etapas que se sucedem no tempo, pois são processos paralelos e superpostos, ás vezes contraditórios. São faces diferentes de um mesmo fenômeno que não respondem necessariamente a uma lógica linear.

A afirmação de MANDELL (1986) corrobora essas afirmações indicando que a criação do esporte moderno foi um processo contínuo de desenvolvimento das práticas corporais. Segundo ele:

"Atletas, fãs e empresários não se limitaram exclusivamente a regulamentar e a desprovincializar as velhas atividades recreativas das diferentes classes da sociedade mas também impulsionaram a difusão dos novos esportes orientados à obtenção do êxito" (Pág 161).

É possível ainda notar a presença do processo civilizador na formação do esporte nas public schools. Como foi dito, já havia uma prática corporal por parte dos alunos, porém ela não se desenvolveu em virtude de ser considerada rude e vulgar, por estar separada do conjunto relacionado à vida escolar e também por não ser uma pratica unificada. 
Em outro momento, foi preciso que os estudantes deixassem de se confrontar, entre si e contra os diretores das escolas, e passassem a discutir e se tolerar para criar as regras e unificálas.

Das teorias decorrentes das apostas, pode-se inferir que a rivalidade presente nas apostas auxiliou no processo de apropriação pelo sistema de ensino aristocrático pois permitiu transportar esses embates dos bares e locais de aposta para os campos.

SALVADOR (2004) corrobora essas informações afirmando que o alto grau de autonomia das public schools somado à grande rivalidade, tensão e competição entre essas escolas foi uma das condições para a criação do futebol e do rugby.

Outra possibilidade de convergência entre a teoria do esporte de apostas e o processo civilizador, indica que o fato de os apostadores poderem deixar de ser pacientes da ação, para se tornarem agentes, buscando, no campo, vencer a sua aposta, pode ter auxiliado na apropriação por parte dos estudantes, das novas formas de prática corporal proposta pelos educadores.

Em uma outra vertente sobre o surgimento do esporte HOBSBAWM (1988) analisa o desenvolvimento das práticas esportivas através da invenção das tradições:

"Por "tradição inventada" entende-se um conjunto de práticas, normalmente reguladas por regras tácita ou abertamente aceitas: tais práticas, de natureza ritual ou simbólica, visam inculcar certos valores e normas de comportamento através da repetição, o que implica, automaticamente, uma continuidade em relação ao passado” (Pág. 09). 
De acordo com o autor, o período de origem do esporte moderno coincide com - e é resultado de - um momento histórico de produção em massa das tradições: o final do século XIX e início do século XX.

As tradições são divididas em políticas (ou oficiais) e sociais (ou não-oficiais). As tradições políticas são definidas como aquelas

"surgidas acima de tudo em estados ou movimentos sociais e politicos organizados, ou criadas por eles" (Pág. 271).

As tradições sociais se referem àquelas

"geradas por grupos sociais sem organização formal, ou por aqueles cujos objetivos não eram específica ou conscientemente políticos, como os clubes e grêmios, tivessem eles ou não também funções políticas" (Pág. 271).

Segundo o autor, o dinamismo do final do século XIX gerou grupos sociais, ambientes e contextos sociais inteiramente novos, ou velhos, mas incrivelmente transformados que exigiam a necessidade de instrumentos que assegurassem identidade e coesão social, e que estruturassem as relações sociais.

Neste momento da história o homem comum tinha cada vez mais direito de participar do Estado. Em função disso, as classes existentes na sociedade, especialmente a classe operária, tendiam a identificar-se através dos movimentos políticos ou organizações de âmbito nacional. Conseqüentemente, a maior participação social na política gerou um 
enfraquecimento dos velhos mecanismos através dos quais se mantivera com êxito a subordinação social até então.

Era necessário, assim, estabelecer padrões que caracterizassem as classes altas da sociedade, uma vez que era um momento em que as profissões reivindicavam status de classe média-alta e que o número de pessoas que aspiravam a essa determinada classe crescia com relativa rapidez nos países em fase de industrialização.

A educação tinha um papel importante, mas não determinante nessa divisão. Ter apenas a educação primária classificava a pessoa como membro das classes inferiores, com a educação secundária reconhecia-se um status de classe média. A educação superior era o passaporte para a alta classe média e outras elites.

No entanto, o crescente número de estudantes fez com que se definisse a elite efetiva dentro de um conjunto cada vez maior daqueles que possuíam o passaporte educacional exigido.

O artifício informal básico para a estratificação era a escolha individual de parceiros sociais aceitáveis, o que era conseguido através da adesão aristocrática ao esporte, transformado num sistema de disputas formais contra antagonistas considerados à altura em termos sociais (HOBSBAWM, 1988).

Tal informação pode ser ilustrada pelo trabalho de FRANCO JR. (2007) quando da formação dos clubes de futebol pelo mundo. Segundo ele, o nascimento das equipes esportivas futebolísticas está intimamente ligado à escolha de parceiros aceitáveis como entre os trabalhadores das fábricas ou os aristocratas.

Em uma outra observação sobre a história social dos esportes HOBSBAWM (1988), afirma que as últimas três décadas do século XIX assinalam uma transformação decisiva na difusão de velhos esportes, na invenção de novos e na institucionalização da maioria; que essa 
institucionalização constituiu uma vitrine de exposição para o esporte; que o esporte era um mecanismo para ampliar as atividades até então confinadas à aristocracia e à burguesia endinheirada capaz de assimilar o estilo de vida aristocrático, de modo a abranger uma fatia cada vez maior das classes médias, e conclui afirmando que a institucionalização constituiu um mecanismo de reunião de pessoas de status social equivalente, embora sem vínculos orgânicos sociais ou econômicos.

Para HOBSBAWM (1988) o esporte combinava elementos das tradições políticas e sociais. Por um lado representava uma tentativa consciente de formar uma elite dominante que se associasse a elementos conservadores e liberais nas classes médias e altas locais. Por outro, representava uma tentativa mais espontânea de traçar linhas de classe que isolassem as massas, principalmente pela ênfase no amadorismo como critério do esporte de classe média e alta. Representava ainda uma tentativa de desenvolver um novo e específico padrão burguês de lazer, um estilo de vida e um critério flexível e ampliável de admissão num grupo.

Ainda em uma união das tradições sociais e políticas, o esporte constituiu-se em um meio de identificação nacional e comunidade artificial, visto que evidenciou os laços que uniam todos os habitantes do estado nacional, independentemente das regiões, principalmente quando dos campeonatos internacionais que completaram os nacionais.

Um último aspecto que relaciona a invenção das tradições ao esporte diz respeito às praticas ligadas às classes ou camadas sociais específicas. Embora algumas dessas práticas fossem criadas para serem diferenciadores da consciência de classe, uma grande quantidade delas não era tão identificada na teoria, sendo adaptações ou apropriações de práticas originalmente criadas pelas classes sociais mais altas. E o esporte é um exemplo disso.

Criado pelas classes mais altas, HOBSBAWM (1988) identifica no esporte três formas de diferenciação entre elas. A primeira se refere à manutenção, pela aristocracia, do controle 
sobre as instituições que geriam o esporte. A segunda disserta sobre a exclusividade social pelo alto custo ou ausência do equipamento fundamental necessário para a prática. A última diz respeito à rígida separação entre o amadorismo, o critério do esporte entre as camadas superiores, e o profissionalismo, seu representante óbvio entre as classes baixas urbanas e operárias.

Sobre os esportes específicos da classe operária, o autor assegura que ele raramente evoluiu conscientemente como esporte, e onde isso se deu, foi geralmente pela apropriação de práticas das classes altas, expulsão dos antigos praticantes e desenvolvimento de um conjunto específico de procedimentos sobre uma nova base social.

A conclusão sobre essas teorias é a de que o esporte é resultado da influência burguesa na sociedade inglesa e, em virtude da fácil assimilação e de suas características decorrentes do processo civilizador, difundiu-se para as demais partes do mundo. É certo que a influência econômica inglesa no período auxiliou muito no processo de difusão das modalidades, mas o fato de algumas modalidades serem mais aceitas em alguns lugares demonstra que a aceitação dependia também das características das respectivas sociedades.

DUNNING (1997) conclui que é possível pensar o caminho que conduz à regulamentação inicial das práticas físicas em duas vertentes. A primeira é resultado das práticas do século XVIII e contempla o cricket, o golfe e a caça. A segunda é proveniente do século XIX e abrange o futebol, o rugby, o tênis e o atletismo. Eu acrescentaria ainda uma terceira forma de desenvolvimento do esporte que é um amálgama das práticas do séc. XIX, mas que se diferencia das demais pela sua importância econômica, conforme a explicação de BROHM (1982). Nesse grupo se encaixariam as corridas a pé e a cavalo e o boxe, por serem de alto potencial econômico desde os primórdios. Importante notar que, apesar de serem quase 
que na totalidade criadas pelas classes mais altas, nenhuma delas era exclusivamente aristocrática ou popular, e que seus praticantes vinham de ambas as classes.

Cabe ressaltar que apesar de não ser do escopo desse trabalho, outras formas de prática corporal existiam na época e também eram organizadas. Os movimentos ginásticos de países como Alemanha, França, Suécia e Dinamarca, em função da posição geográfica e das eminências de guerra, visavam a preparação para a luta armada e para a defesa do território.

$\mathrm{Na}$ Inglaterra, apesar de sua posição geográfica privilegiar a defesa marítima, o sistema ginástico foi implantado nas classes menos favorecidas, buscando com isso uma formação higienista e de aceitação tácita de ordens, o que contrastava com a formação dos líderes nas escolas públicas (RUBIO, 2001).

Passa-se agora ao estudo de outra conseqüência da gênese do esporte moderno: o Movimento Olímpico

\subsection{ORIGENS DO MOVIMENTO OLÍMPICO}

A criação do Movimento Olímpico está diretamente relacionada ao momento de desenvolvimento e difusão do esporte moderno. Pierre de Freddy, criador dos Jogos Olímpicos e do conceito moderno de Olimpismo foi um homem marcado pelas características de seu momento histórico, como veremos a seguir.

De acordo com TAVARES (2003), Pierre criou uma instituição - o Comitê Olímpico Internacional (COI) - destinada a promover sua causa e guardar seus valores, no entanto, a formação da mesma em bases não formalmente democráticas gerou continuamente críticas e controvérsias a seu respeito. 
Para ZAKUS (1992), foi através dos ideais e pensamentos filosóficos do nobre francês que o Movimento Olímpico estabeleceu suas bases e sua estrutura operacional.

O momento de criação dessa estrutura, entretanto, é de grande turbulência no cenário mundial, assim, não é difícil associar a turbulência do momento às controvérsias da instituição. SEVCENKO (2001) classifica o período em questão como um momento de revolução e com modificações abruptas que deturpam as referências de espaço e das circunstâncias que cercam os habitantes. Segundo ele, a responsável por essas características foi a revolução científico-tecnológica, da qual surgiram as usinas termo e hidroelétricas, os motores de combustão interna, as indústrias químicas, e de mineração, além dos novos meios de comunicação. É nesse cenário de grandes modificações que se insere o criador dos Jogos Olímpicos.

Nascido na França na segunda metade do século XIX, o nobre que também atendia pela alcunha de Barão de Coubertin, ficou marcado, como lembra McINTOSH (1975), pela derrota francesa na guerra Franco-Prussiana de 1871. Tal fato estimulou uma preocupação com a educação e preparação das gerações seguintes. Como conseqüência o Barão se convenceu da necessidade de reformulação dos métodos de educação franceses (TAKÁCS, 1992).

Para MANDELL (1986), Coubertin assumiu a idéia de que deveria dedicar sua vida ao crescimento da preponderância cultural e política de seu país, imaginando formas de fortalecer a posição da França no cenário internacional.

A guerra ou a eminência dela foi um fator sempre presente no final do séc. XIX e que também influenciou Coubertin. De acordo com HOBSBAWM (1992) a possibilidade de uma guerra na Europa preocupava tanto governos como o público mais amplo. O serviço militar, além de proteger o território, tinha ainda a função de inculcar o comportamento cívico 
apropriado e de transformar o habitante de um povoado no patriota de uma nação. Função que também seria atribuída ao esporte.

Já na década de 1880 inicia-se uma corrida armamentista, propiciada pelos avanços tecnológicos e inflamada pelo desejo de permanecer à frente nessa disputa (HOBSBAMW, 1992). A guerra ainda teria influência na criação de instituições pacifistas como veremos mais adiante.

Além do fator externo, RUBIO (2006) afirma que Coubertin estava descontente com a sociedade francesa e buscava uma maneira de promover ações para modificar o quadro de uma França que em menos de um século passou por três monarquias, dois impérios e três repúblicas. Tal fato corrobora a afirmação de TAVARES (2003) de que a atitude do barão em relação ao sistema político como instituição era de permanente descrença.

TAVARES (2003) afirma ainda que Coubertin viveu uma permanente tensão entre o desejo de participar da vida pública francesa e a descrença na política e também entre suas origens conservadoras e o mundo novo que gostaria de ajudar a criar.

Sendo assim, ele se convence de que a maneira de resolver os problemas de seu povo seria através da educação, e por isso ingressa na École Supérieure des Sciences Politiques, fundada por Hipólito Taine. Ali o barão encontra um importante núcleo de estudos relacionados à Inglaterra, que almejava compreender as razões da estabilidade e progresso do império britânico.

Dentre as diversas características da sociedade inglesa estudadas por Coubertin, duas, que foram citadas no capítulo precedente e que foram destacas por Taine em seus trabalhos, possuem particular importância na sua idéia de recriar os Jogos Olímpicos. A primeira diz respeito ao sistema educacional inglês, com suas atividades esportivas. E a segunda ao espírito de associação da sociedade inglesa. 
O conhecimento de Coubertin sobre a Inglaterra não era apenas teórico, pois na busca de seu projeto esportivo-pedagógico ele visita escolas inglesas e até americanas e conclui que o sistema esportivo disseminado por Thomas Arnold seria de fundamental importância no seu projeto. Para Coubertin, Arnold havia desenvolvido um sistema educacional baseado no desenvolvimento moral, nas atividades físicas e na educação social, tendo como eixos centrais a liberdade e os esportes. RUBIO (2006) complementa que:

“A fundamentação dessa pedagogia se assentava na responsabilidade e na hierarquia. A responsabilidade estava associada ao uso da liberdade e do cumprimento de normas e tradições que, entre outras ações, refletia-se no uso do tempo ocioso. A hierarquia demandava a compreensão e aceitação de uma 'ordem natural' imposta pelos veteranos, por aqueles que primeiro chegaram à instituição impondo a perpetuação de uma cultura que deveria ser reproduzida pelos mais novos.” (Pág. 53 )

Para TAVARES (2003), Coubertin atribuía ao esporte um valor educativo e um papel de mimese das relações numa sociedade democrática.

Sobre o espírito de associação da sociedade inglesa, como vimos anteriormente, ele era fruto do processo civilizador proposto por ELIAS (1992) e possibilitado pela não proibição, ou pelo estímulo a essas associações; e também fruto da impossibilidade de se definir claramente as classes sociais, conforme HOBSBAWM (1988). 
Um outro autor que influenciou o barão sobremaneira foi Fréderic Le Play. Para RUBIO (2006) é em Le Play que a reforma social de Coubertin, por meio de uma pedagogia esportiva, encontrará seu porto seguro.

De acordo com TAVARES (2003), Le Play desenvolveu uma filosofia política e social baseada em valores da família, paz social e moralidade pessoal. Este sociólogo e filósofo francês acreditava que a descrição científica, o conhecimento exato e o progresso contribuiriam para a paz social e para a harmonia entre as classes e que estes objetivos transcenderiam as ideologias políticas.

Interessante ressaltar nessa passagem que as contribuições à paz social e à harmonia de classes corroboram a desestruturação das classes sociais vistas anteriormente, e o fato de transcender à política confirma a descrença de Coubertin nesse sistema.

Um discurso de Coubertin sobre as idéias das instituições de Le Play afirma o ideal de tradição social, explicitada por HOBSBAWM (1988), dessas associações:

\footnotetext{
"Nosso programa vai seduzi-los por que ele não pertence a nenhum partido ou seita; por que ao adotá-lo não se sacrifica qualquer crença ou fidelidade uma vez que ele resolutamente deixa de lado recursos puramente politicos que nosso país tem freqüentemente tentado e que tem causado tanta amarga desilusão." (MacALOON, 1984. Pág.88).
}

Concomitantemente aos estudos de Coubertin ocorria o renascimento do interesse pelos estudos clássicos e as descobertas de sítios arqueológicos que elucidavam acontecimentos relacionados aos Jogos Olímpicos da Antiguidade, reavivando o fascínio exercido pela cultura helênica sobre a cultura européia (RUBIO, 2006). TAKÁCS (1992) 
complementa informando que o Barão era um Helenófilo que admirava a Grécia antiga e buscava reviver toda tradição ancestral.

Foi da união das idéias de reformulação educacional, com forte influência esportiva, com a redescoberta dos Jogos Olímpicos da Antiguidade que Coubertin formulou a idéia de reeditar os Jogos Olímpicos.

Com os Jogos, o barão almejava valorizar a competição leal e sadia. De acordo com RUBIO (2006), ele buscava revalorizar os aspectos pedagógicos do esporte mais do que assistir à quebra de recordes, diferenciando assim a sua visão de esporte da visão de BROHM (1982) exposta acima. Segundo a mesma autora, o francês empenhou-se em:

“organizar uma instituição de caráter internacional com a finalidade de cuidar daquilo que seria capaz de transformar a sociedade daquele momento: o esporte”. (Pág.54)

Em 1892 foi apresentado o projeto de recriação dos Jogos Olímpicos, manifestando o desejo de seu idealizador de internacionalizar o esporte. Para tanto, seria necessária uma instituição que gerisse essa obra. Seguindo o modelo inglês de associação, em 1894 o Barão apresenta, no congresso esportivo-cultural em Paris, a proposta de recriação dos Jogos Olímpicos. Jogos esses sob a coordenação do recém criado Comitê Olímpico Internacional, que tinha a missão de organizá-los, bem como normatizar as modalidades disputadas, muitas delas recém criadas e sem um corpo de regras universalizadas.

Um fator adicional, além da reforma educacional e da redescoberta grega, que influenciou na criação do COI foi, conforme explica TAVARES (2003), a acelerada proliferação de um amplo espectro de organizações internacionais, cujo intuito era a promoção 
da paz e oposição à guerra. A oposição à guerra, complementa o autor, não significava a abolição da idéia de competição e conflito, mas sua substituição por atividades dentro de normas que organizassem as nações civilizadas, tendo os interesses comuns como referência.

SEPPANEN (1984), afirma que segundo os ideais e metas de Coubertin, os Jogos Olímpicos Modernos poderiam estabelecer uma base permanente para a paz mundial e para o entendimento mútuo entre os homens.

Ainda segundo TAVARES (2003), a respeito da criação do COI, sendo um idealista de seu tempo, Coubertin buscava soluções para a instabilidade política e social de seu país natal e posteriormente no plano da construção das relações internacionais pacíficas. Nesse sentido, o esporte é, aos olhos de Coubertin, uma ferramenta de educação física, moral e social e não um fim em si mesmo.

A idéia de internacionalização e normatização das regras e modalidades disputadas corrobora o processo civilizador de ELIAS (1992), ampliando sua abrangência para além do continente europeu, e reproduzindo as correntes pacifistas muito em voga no período.

A realização dos Jogos seria de quatro em quatro anos, a princípio juntamente com as grandes exposições internacionais que ocorriam na época. Estas exposições sintetizavam a combinação das idéias de progresso, paz e internacionalismo e já possuíam uma magnitude significativa, o que atraía a atenção de Coubertin (TAVARES, 2003).

A idéia inicial do barão era realizar a primeira edição dos Jogos em Paris, no ano de 1900, juntamente com a exposição internacional e a celebração da virada do século. No entanto, como coloca RUBIO (2002), em homenagem aos fundadores dos Jogos Antigos, a primeira edição foi antecipada para 1896 e ocorreu em Atenas, na Grécia. 
Movendo-se dos fatos para as idéias, SEPPANEN (1984) classifica o Movimento Olímpico como um movimento transcultural e transnacional que tenta implantar sua crença, ou sua ideologia, no seio da humanidade através de competições esportivas internacionais.

Além disso, algumas particularidades do COI, em função de serem reflexo das idéias de Coubertin, são controversas e geram discussões ainda hoje. Dentre essas se discutirá mais profundamente a questão da forma de gestão do COI, o fair play e o amadorismo. A questão da participação feminina nos Jogos também apresenta sua controvérsia nas bases do COI, mas não será aprofundada neste trabalho. De acordo com GUTTMANN (1978) a exclusão das mulheres nas primeiras edições dos Jogos, está ligada à sua proteção, por ser compreendida como frágil, enquanto que a exclusão, por exemplo, dos negros se baseava na discriminação.

Sobre a forma de gestão implantada por Coubertin no Comitê Olímpico Internacional, ela é não ideológica e não democrática, moldada segundo o modelo de organizações fechadas destinadas à promoção de objetivos sociais que o francês conhecia das organizações pacifistas de Le Play, o que vai contra a gestão das organizações esportivas estudantis que o próprio Coubertin via como modelo positivo de organização democrática.

Segundo TAVARES (2003), o COI era mais uma entre as diversas organizações internacionalistas de seu tempo, e se apoiava na idéia de ser não-ideológica, promover uma idéia, se organizar em torno de uma elite e servir a humanidade em regime de independência de correntes políticas e governos nacionais.

Para RUBIO (2006), essas seriam as bases de um movimento que se propunha internacional, apolítico e apartidário. Em conseqüência disso o movimento foi amparado na força dos Comitês Olímpicos Nacionais e principalmente na cooptação e atuação dos membros do comitê. 
Para o idealizador dos Jogos, o caráter fechado e elitista do COI garantiria, pela independência dos seus membros, uma alternativa de estabilidade em oposição à democracia política que era vista por ele como defeituosa ou limitada (RUBIO, 2006).

O ingresso de membros no Comitê Olímpico Internacional é tido por HARGREAVES (1992) como uma possibilidade de atrair a presença de países em que o Estado controla o esporte. Além disso, para dar suporte a sua recém criada iniciativa, Coubertin precisava do suporte de figuras nacionais de prestigio, cujo status enalteceria a importância de sua entidade.

Assim, os membros do referido comitê são compostos por representantes de várias nacionalidades indicados pelos participantes do encontro de Paris e o ingresso até hoje se dá apenas por indicação. Aos que criticaram essa forma de ingresso Coubertin se defendeu dizendo que está ciente da sua decisão, mas que tem prazer em tomar a responsabilidade por seus atos.

De uma análise das influências sobre Coubertin conclui-se que não se poderia esperar uma forma de gestão muito diferenciada, pois do sistema eleitoral ele era descrente. A única forma de associação por ele conhecida era de pessoas da mesma classe e que supostamente tinham interesses comuns. Sendo freqüentador e mais ativo nesse tipo de associação, era muito mais fácil de se perceber benefícios do que aqueles provenientes dos poderes públicos, assim, não fica difícil entender por que mesmo dando margem a críticas, ele escolheu esse modelo.

TAVARES (2003) propõe a interpretação das propostas de Coubertin à luz das idéias de Robert Michels, um sociólogo alemão que afirma que a democracia e grandes organizações sociais são incompatíveis uma vez que a despeito de seus objetivos e ideais elas desenvolvem rígidas e permanentes oligarquias internas. E uma vez que o COI possui interesses bem definidos, padrões claros de atividade e modelos de regulação e controle relacionados a seus 
propósitos, não fica difícil defini-lo como uma organização burocrática racionalmente organizada.

O documento que norteia o COI e a organização e operação do Movimento Olímpico é a Carta Olímpica, escrita por Coubertin no ano de 1898. Ela é a codificação dos princípios fundamentais e regulamentos adotados pelo COI. Tal codificação mais uma vez corrobora o processo civilizador, pois foi aceita e aprovada por representantes de diversas nacionalidades.

Antes de concluir sobre o modo de gestão do COI vale ressaltar que conforme nos lembra BOUDON \& BOURRICAUD (1993) a palavra democracia pertence ao vocabulário da ideologia, podendo o mesmo vocábulo se referir a dois ou mais tipos de democracia diferentes.

Passemos agora a compreender melhor outro fator de discussão decorrente do Olimpismo: o fair-play.

Também denominado jogo limpo, espírito esportivo ou ética esportiva, esse elemento pode ser definido como um conjunto de princípios éticos que orientam a prática esportiva, principalmente do atleta mas também dos demais envolvidos com o confronto esportivo.

O fair-play presume uma formação ética e moral daquele que pratica e se relaciona com os demais atletas na competição, presume ainda que este atleta não fará uso de outros meios que não a própria capacidade de superar os oponentes (RUBIO, 2006).

Sua gênese está ligada ao conceito de cavalheirismo inglês, conceito que contempla a nobreza de caráter, os valores cristãos e humanistas relacionados ao Renascimento. Esse era o conceito que definia a base do ideal de homem na sociedade inglesa do século XIX (RUBIO, 2006; TAVARES, 1999).

Segundo RUBIO (2006), a transposição dessa atitude para o âmbito esportivo se deu desde o surgimento do Movimento Olímpico contemporâneo. Sendo assim, o conceito do 
espírito esportivo foi concebido a partir de uma perspectiva cultural dominante, decorrente da Inglaterra, em um momento em que a estrutura e a organização olímpica restringiam-se a um grupo restrito de pessoas que não tinham outros além de si para basear a criação das regras.

Retomando as idéias de ELIAS (1992) de que o processo civilizador não excluía as idéias de suborno, e entendendo o esporte e o fair play como conseqüências dessa mesma sociedade neste mesmo momento histórico, parece ser possível afirmar que além do jogo limpo seria necessário, para se obter um bom espetáculo, o embate entre dois opostos que tivessem como objetivo maior a vitória. Do contrário, um confronto armado em função das apostas, denegriria a imagem do esporte, mesmo sendo pautado pelo conjunto de valores éticos.

Ainda no processo civilizador, a aceitação das regras e condutas pelos demais praticantes e a regulamentação das mesmas são fatores que confirmam o processo no esporte.

A questão do amadorismo, que atualmente para o COI faz parte dos livros de história, foi uma outra polêmica que se discutiu muito não só no âmbito olímpico, mas também em várias outras modalidades desde a fundação do COI até os Jogos de Los Angeles em 1984.

Criado por aristocratas o esporte carregava as idéias da aristocracia e da burguesia, ou seja, era permitido apenas para amadores, termo que designava as pessoas que não trabalhavam nem exerciam nenhuma atividade remunerada (LICO \& LEMOS, 2007).

O amadorismo se constituiu como um dos pilares do Movimento Olímpico em função de o esporte em si ter sido criado pelos aristocratas e para os aristocratas, bem como o Olimpismo. Assim, a ênfase era dada à prática desvinculada do trabalho visando mantê-la sob os domínios de seus "criadores".

Com o passar dos anos e devido à sua fácil assimilação, o esporte passou a ser praticado também por pessoas de outras camadas sociais e que começaram a ganhar destaque 
nos confrontos. Assim, o conceito de amador passou a caracterizar aqueles que até poderiam exercer atividade remunerada mas em áreas que não tivessem ligação com a prática esportiva. Por fim, passou-se a aceitar os denominados profissionais, que são aqueles que são pagos em função da atividade esportiva.

RUBIO (2006) acrescenta ainda à discussão que o conceito de amadorismo se viu envolvido em ambigüidade devido à divisão do mundo em blocos capitalista e socialista, sendo que neste último:

"o argumento da socialização dos meios de produção era utilizado para negar a existência de profissionais do esporte, afirmando a condição amadora de todos seus atletas-cidadãos.” (Pág.66)

Em virtude dessa ambigüidade o status de atleta passou a ser determinado por questões internas dos diversos Estados participantes dos Jogos.

Como conseqüência das modificações no mundo e do descaso de Coubertin sobre o assunto - em seu livro de memórias ele afirma que essa questão nunca foi importante pra si o amadorismo foi sendo esquecido e deu lugar ao profissionalismo a partir dos Jogos de Los Angeles em 1984 (RUBIO, 2006).

O que chama a atenção sobre o desprezo de Coubertin pela questão do amadorismo, e mesmo assim tendo incorporado a idéia ao Movimento Olímpico, é a presença do jogo de interesses desde os primórdios do Olimpismo, pois, em função da importância que o amadorismo tinha para a comunidade britânica e do peso político desse grupo numa instituição apolítica, o barão achou melhor se posicionar contra o perigo que o 
profissionalismo poderia representar para o movimento. Desse modo nota-se que a presença da política ocorre desde as origens do COI.

Os conceitos que giram em torno do Comitê Olímpico Internacional merecem destaque para que não se incorra em erros. O termo Olimpíadas designa o período de quatro anos que separa duas edições dos Jogos Olímpicos, que por sua vez são os dias de realização das festividades e embates esportivos. Olimpismo e Movimento Olímpico indicam conforme a carta olímpica (2001):

"uma filosofia de vida que exalta e combina em equilíbrio as qualidades do corpo, espírito e mente, combinando esporte com cultura e educação. O Olimpismo visa criar um estilo de vida baseado no prazer encontrado no esforço, no valor educacional do bom exemplo e no respeito aos princípios éticos fundamentais universais” (Pág. 8)

Após discorrer sobre os primórdios do Movimento Olímpico, dissertaremos agora sobre o ingresso das idéias de Coubertin no cenário brasileiro e suas implicações.

\subsection{MOVIMENTO OLÍMPICO NO BRASIL}

O desenvolvimento do Olimpismo no Brasil se deu juntamente com o desenvolvimento de outras instituições gerenciais esportivas em âmbito nacional.

De acordo com RUBIO (2006), no final do séc. XIX já se praticavam no Brasil, de maneira regular, o remo, a natação, o basquetebol, a esgrima e o futebol, sendo este último o que mais se adequou à sociedade brasileira. 
A partir das agremiações inglesas e da proliferação de instituições internacionalistas, chega ao Brasil o convite para se unir aos países europeus através da organização nacional de seu setor esportivo (RUBIO, 2006).

No território brasileiro já haviam as instituições regionais e inclusive já havia brigas entre as mesmas como mostra RIBEIRO (2000) sobre a realização de campeonatos de futebol. De acordo com o autor, os desentendimentos giravam em torno da aceitação ou não de jogadores profissionais ou de camadas mais pobres da sociedade.

O ingresso brasileiro no Movimento Olímpico ocorre, segundo FRANCESCHI NETO (1999), em 1913, quando da realização do Congresso Olímpico Internacional em Lausanne hoje cidade sede do Museu Olímpico. De acordo com a autora, nesse encontro Pierre de Coubertin, então presidente do Comitê Olímpico Internacional, convida o Ministro do Brasil na Suiça, Raul do Rio Branco, a integrar a entidade por ele presidida e se tornar delegado do Brasil na instituição.

A atitude de Coubertin demonstra claramente a intenção única de expandir a internacionalização de sua instituição, uma vez que ele pouco conhecia sobre o país.

Após alguma relutância por não conhecer a realidade do esporte no Brasil, Rio Branco é convencido pelo próprio Coubertin e aceita o convite embalado pela proposta de colocar o Brasil entre as grandes nações (RUBIO, 2006). Como membro do COI ele escreve aos dirigentes brasileiros incitando uma colaboração no sentido de criar um comitê olímpico nacional e também na indicação de outros representantes para integrar o referido comitê (FRANCESCHI NETO, 1999).

A mesma autora afirma ainda que Rio Branco foi muito prudente ao escrever ao Brasil, pois ele ressalta a necessidade de primeiro se divulgar os ideais olímpicos para depois se discutir a participação nos Jogos Olímpicos. 
A fundação do Comitê Olímpico Nacional (CON) se dá após pouco mais de um ano da entrada de Raul do Rio Branco no COI. A data da fundação é de oito de junho de 1914, seu objetivo era de permitir a admissão brasileira nos Jogos Olímpicos e seu estatuto baseava-se no estatuto do Comitê Olímpico Português.

Estavam presentes na ocasião representantes da Liga Metropolitana de Esportes Atléticos, da Federação Brasileira de Sociedades de Remo, do Automóvel Clube Brasileiro, da Comissão Central de Concursos Hípicos, do Clube Ginástico Português, do Centro Hípico Brasileiro, do Jockey Club Brasileiro e do Aeroclube Brasileiro. Além da formação do CON, formou-se também na mesma reunião a Federação Brasileira de Sports (FBS), que em 1916 passou a ser chamada de Confederação Brasileira de Desportos (CBD) e no final da década de 1970 se tornou Confederação Brasileira de Futebol (CBF) (COB, 2003).

Assim, do convite de Coubertin, se organiza no Brasil o Comitê Olímpico e a Federação Brasileira, entidades que tinham ideais diferentes, porém complementares, afinal era da organização do esporte nacional e da preparação para as competições nacionais e internacionais que surgiriam as equipes que o comitê se esforçaria para levar aos Jogos Olímpicos. De acordo com o COB (2003), a partir da fundação, o CON e a FBS nada mais tinham em comum do que a fundação no mesmo dia, no mesmo local e pelas mesmas entidades.

A criação das referidas entidades em 1914, no entanto, não foi um processo simples e harmônico. Em 1913 quando Rio Branco escreve ao Brasil solicitando a criação do CON, os estados de São Paulo e Rio de Janeiro já contavam com associações representativas dos esportes e ao receber a notícia de Rio Branco, elas se organizam para tentar criar a primeira entidade nacionalmente representativa do país. Acontece que as organizações paulistas mais 
representativas passavam por um momento de crise em virtude de divergências econômicas e idealistas (RIBEIRO, 2000).

Segundo o mesmo autor, em 1913, dirigentes do Club Athlético Paulistano (CAP), clube altamente influente no esporte em São Paulo, se desentendem com os dirigentes da Liga Paulista de Futebol, então responsável pela organização dos campeonatos da modalidade no estado, e fundam, a Associação Paulista de Esportes Atléticos (APEA) abrigando não só o futebol, mas diversas outras modalidades sob sua responsabilidade.

Desse modo, e almejando o reconhecimento, ambas as instituições procuram demonstrar um melhor gerenciamento do esporte, uma imagem de entidade mais representativa e também procuram buscar o apoio de outras entidades representativas, como por exemplo, a Liga Metropolitana de Esportes Atléticos (LMEA), do Rio de Janeiro, para se firmar nesse contexto de instabilidade.

Nesse sentido, a associação da APEA com a LMEA e a intervenção da entidade carioca no cenário paulista é providencial para impedir que as associações de São Paulo façam as pazes e assim tenham condições de pleitear o cargo de entidade mais representativa do país ou de se organizar para fundar o CON e a FBS. Não se sabe é se esta era ou não a intenção da LMEA, sabe-se apenas que a entidade responsável pelo futebol da Argentina, que já fazia parte do quadro da FIFA, ou seja, já possuía o status de representante nacional, trabalhava para a reconciliação das duas entidades paulistas.

A eclosão da primeira Guerra Mundial foi responsável, segundo documento do COB (2003), pela não participação do Brasil nos Jogos Olímpicos de 1916 em Berlim (jogos que não ocorreram em função da guerra), pela pouca atividade da diretoria empossada três dias após a fundação do $\mathrm{CON}$ e pela apropriação, por parte de $\mathrm{CBD}$, da organização das equipes que participaram dos Jogos Olímpicos entre 1920 e 1932. Sobre os Jogos em Berlim, no 
entanto, uma carta escrita pelo próprio Raul do Rio Branco em 1913 e citada por FRANCESCHI NETO (1999) indica que ele acreditava que dificilmente a escolha e preparo dos atletas e as despesas da viagem poderiam ser suportadas pelas organizações esportivas brasileiras da época.

O período que se seguiu entre a fundação do CON em 1914 e a fundação do COB em 1935 foi um período, como se verá a seguir, decisivo na consolidação da participação brasileira no Movimento Olímpico.

Em 1920, após a primeira grande guerra, o Brasil participa da sua primeira edição dos Jogos Olímpicos em Antuérpia na Bélgica. Já nessa ocasião, segundo documentos do COB (2003), a organização e direção das equipes que foram aos Jogos estavam a cargo da CBD. É em Antuérpia que o Brasil consegue sua primeira medalha de ouro olímpica, com Guilherme Paraense no tiro.

Dois anos depois, em 1922, o Brasil comemorou o centenário da independência, e, baseando-se nos moldes olímpicos, em que os jogos eram realizados conjuntamente com outros eventos como feiras e exposições internacionais, pediu e recebeu o apoio do COI, dando ao evento o status de jogos extra-olympiadas. Desse modo, o governo brasileiro incumbiu a CBD de organizar os jogos comemorativos do centenário. Segundo FRANCESCHI NETO (1999), estes foram os primeiros jogos regionais da América Latina.

A realização dos jogos em 1922 possibilitou um grande desenvolvimento para o esporte no Brasil, não só nos recursos físicos, através da criação e reformas de parques esportivos, mas também com relação aos recursos humanos. Na ocasião dos jogos, segundo FRANCESCHI NETO (1999), o então vice-presidente do COI, Conde de Baillet-Latour, que fazia uma visita para conhecer a real situação do esporte na América Latina, passa pelo Brasil. 
Com a visita, Baillet-Latour toma contato com alguns expoentes da organização esportiva brasileira. Tal encontrou rendeu, no ano seguinte, o convite para o ingresso no COI a Arnaldo Guinle e José Ferreira Santos, sendo aquele presidente do Fluminense Football Club no Rio de Janeiro e este membro da APEA em São Paulo. As conseqüências do ingresso destes dois brasileiros, desta vez mais envolvidos com a realidade do esporte no país, seriam aproveitadas principalmente no ano seguinte por ocasião dos Jogos Olímpicos de Paris.

A participação brasileira nos Jogos Olímpicos de 1924 gerou discussões entre os representantes do esporte nacional e contribui para acirrar as disputas na organização do esporte brasileiro.

Em virtude da insuficiente quantia concedida pelo governo brasileiro para as despesas com os Jogos na França, a CBD teve de selecionar algumas equipes em detrimento de outras para a participação no evento. Na seleção a equipe de atletismo ficou de fora, provocando um forte descontentamento nos responsáveis pelo atletismo em São Paulo, levando-os a protestar contra a entidade.

Após algumas conversas, como coloca FRANCESCHI NETO (1999), foi autorizada a entrada da equipe de atletismo na delegação brasileira, no entanto a CBD não disponibilizaria os recursos para o custeio das despesas da equipe. Sendo assim, o presidente da APEA, Antonio Prado Junior, que era também envolvido com o atletismo e presidente do CAP, organiza juntamente com o diretor de esportes do jornal "O Estado de São Paulo", Américo Netto, uma campanha estadual para levantar fundos para a viagem da referida delegação.

Através da campanha e da forte influência de suas lideranças o dinheiro é rapidamente levantado, porém em função de disputas internas na CBD, o governo retira o apoio financeiro e a CBD retira a inscrição do Brasil dos jogos. Colhem-se nesse momento os frutos da viagem de Baillet-Latour ao Brasil: o outro emissário da representação do atletismo no estado de São 
Paulo era o novo integrante brasileiro no COI, José Ferreira Santos. Assim, ele e Prado Junior realizaram esforços para que o Brasil fosse novamente aceito nos Jogos e o êxito de ambos foi responsável pelo embarque de nove atletas brasileiros para Paris.

Também nesse episódio podemos mais uma vez notar a importância dos membros do COI em função do modelo de gestão adotado por Coubertin quando da criação do Olimpismo.

Em 1928, por problemas econômicos, segundo documentos do COB (2003), o Brasil não compareceu a Amsterdã.

Pode-se perguntar aonde estavam os homens que levantaram o dinheiro em 24 e por que eles não fizeram o mesmo em 28. Uma possível causa seria o envolvimento de Antonio Prado Junior com a política. Sendo um homem público muito respeitado e também filho de um ex-governador do estado de São Paulo, por ocasião da eleição de Washington Luis - indicado paulista na sucessão presidencial que alternava candidatos mineiros e paulistas na chamada de política do café com leite - Prado Junior é convidado, em 1926, pelo então Presidente da República a assumir prefeitura do Distrito Federal (Rio de Janeiro).

A gestão de Prado Junior é outro fato que merece uma atenção especial, pois é provável que tenha sido nesse momento que ele e Arnaldo Guinle, que já tinham tido desentendimentos por conta das instituições esportivas que presidiam (APEA e LMEA, respectivamente) tenham encontrado objetivos comuns que os levaram a caminhar para os mesmos ideais, e entre esses, a fundação do COB em 1935.

Em 1932, sob o governo de Getulio Vargas, Prado Junior é obrigado a se exilar na Europa, a delegação brasileira parte para os Jogos Olímpicos de Los Angeles a bordo de um navio cheio de sacas de café e com dois canhões na popa (RUBIO, 2006). As sacas de café eram para serem vendidas nos portos onde o navio atracasse a fim de se levantar fundos para a inscrição dos atletas nos Jogos. Os canhões eram para poder passar pelo canal do Panamá 
como navio de guerra e assim não pagar as taxas cobradas de navios mercantes. Ao final a venda das sacas foi insuficiente para todos os atletas, fazendo com que apenas alguns pudessem desembargar e participar dos Jogos; e os canhões foram inúteis, pois dado o contingente humano e as sacas de café vistoriadas no navio, a embarcação teve de pagar para atravessar o canal do Panamá.

O ano de 1935 foi mais um ano conturbado no cenário esportivo nacional, principalmente no que diz respeito às organizações esportivas. Sob a alegação da necessidade de se fundar na forma das leis olímpicas e em obediência a elas um Comitê Olímpico Brasileiro e contando com o apoio do Conde de Baillet-Latour, agora presidente do COI, e de Raul do Rio Branco, os membros do COI no Brasil, Arnaldo Guinle e Ferreira Santos, convocam os representantes autorizados de várias instituições nacionais para fundarem e instalarem a entidade em 20 de maio daquele ano. A CBD, visando não perder o espaço já conquistado no âmbito internacional durante os anos que foi responsável pela organização das equipes que iam para os Jogos Olímpicos, cria um outro COB menos de duas semanas depois e durante um período de tempo ainda tenta, através de cartas ao COI, recuperar seu prestígio alegando ser ela a responsável pela organização esportiva brasileira. No entanto, a presença dos membros brasileiros do COI e o apoio do presidente da referida entidade ao outro COB fazem naufragar os esforços da CBD (LEMOS, 2005).

Houve nesse momento uma momentânea disputa de forças envolvendo entidades por trás da $\mathrm{CBD}$ e do novo COB. A primeira tinha o apoio do Presidente da República e a segunda contava com o apoio da entidade maior no âmbito olímpico, o próprio COI.

O reflexo do desentendimento entre as organizações brasileiras se torna mais explícito em 1936 por ocasião dos Jogos Olímpicos de Berlim, quando o Brasil foi representado por duas delegações, uma organizada pelo COB e com o aval do COI e outra pela CBD e com o 
aval do governo federal. O impasse só foi resolvido na capital alemã com a unificação das duas equipes em uma. Mas a solução do problema em Berlim não resolveu os problemas no Brasil.

De acordo com o COB (2003) as participações do Brasil nas edições de 1920 a 1932 foram condicionadas a esforços pessoais dos membros brasileiros do COI, o que facilitaria as disputas por poder.

\subsection{O OLIMPISMO HOJE}

Os dias de hoje e os que estão por vir tendem a continuar as controvérsias. Com relação aos atores do espetáculo esportivo,os atletas, o Movimento Olímpico contemporâneo trás características bem distintas daquelas encontradas no período abordado por esse trabalho. Tomando por base a periodização de RUBIO (2006), atualmente os Jogos se encontram na fase do profissionalismo, o que pela própria denominação já alude à diferença do esporte amador do início do século XX. Século, aliás, caracterizado por seu dinamismo, pelas duas Grandes Guerras, pelo desenvolvimento da informação/comunicação e pela globalização (LICO, 2007; SEVCENKO, 2001).

Olhando para o desenvolvimento dos Jogos Olímpicos e do esporte de maneira geral, faz-se necessário concordar com a característica denominada por HOBERMAN (1984) de transideológica, afinal, nesse "breve século XX" (HOBSBAWM, 1995) o esporte serviu de ferramenta para entidades políticas e ideológicas diametralmente opostas (LICO, 2007).

SEPPANEN (1984) atribui essa utilização ao fato de os Jogos terem se tornado importantes não só para atletas mas também para governos, negócios, e mídia. 
O mesmo autor destaca ainda outros fatores que tornam os esportes tão interessantes aos olhos dos possíveis manipuladores: é inerentemente neutro, refletindo assim, os efeitos desejados pelas partes interessadas; atrai um alto interesse de atletas e espectadores; é uma ferramenta socialmente aceita e que não apresenta riscos e ao mesmo tempo um dos mais importantes canais de extravasamento das emoções; é de fácil compreensão (com relação às regras do jogo), tendo assim vantagens sobre outras expressões culturais como arte e literatura; possibilita a identificação nacional com o atleta compatriota; e finalmente, é a única atividade em que medidas e comparações sobre as conquistas nacionais são feitas de maneira inquestionável.

A forma como o dinamismo do século $\mathrm{XX}$ atuou na sociedade causou novos problemas entre a teoria do Movimento Olímpico e a prática do mundo atual. Segundo MORFORD (1986) o empreendimento de Coubertin criou um dualismo incompatível com o esporte moderno. Escolhendo perpetuar a ideologia do Barão e rejeitar a realidade do esporte moderno, o Movimento Olímpico não apenas comprometeu sua habilidade de lidar com os problemas do atleta moderno no mercado internacional esportivo como também forçou os atletas a aceitarem a hipocrisia como modo de vida.

Partindo do surgimento do Movimento Olímpico, quando ocorria a formação de alguns estados nacionais e a afirmação de outros, e chegando às últimas edições dos Jogos, patrocinadas por entidades privadas e com mascotes e canções-tema, HARGREAVES (1992) levanta a hipótese de podermos estar testemunhando a atrofia do nacionalismo, o triunfo comercial e a crescente irrelevância da polaridade nacionalismo-internacionalismo.

A contradição entre o fato de os membros do COI - que não são representantes de seus respectivos paises na entidade, mas sim representantes dos ideais Olímpicos em sua pátria; e os hinos, bandeiras e quadro de medalhas quando se diz respeito aos atletas, demonstrada por 
LICO (2007) também comprova as dificuldades de se conciliar a teoria e a prática no âmbito Olímpico.

O caráter apolítico pretendido pelo COI também é fortemente questionado, e vem de longa data. RUBIO (2006) indica que Coubertin, numa manobra sagaz, proclamou um grego como presidente do Comitê para assim obter o apoio necessário para realizar a primeira edição dos Jogos na Grécia (substituindo a idéia inicial de realizar a primeira edição na capital de seu país) e obtendo assim, também o simbolismo necessário para relacionar os Jogos Modernos com aqueles da antiguidade.

Para SEPPANEN (1984), o sistema Olímpico foi organizado para ser altamente dependente da ordem política mundial, pois os comitês nacionais são organizados em função das divisões territoriais e nenhum atleta pode participar dos jogos se não estiver relacionado a alguma equipe nacional. Afirma o mesmo autor que, apesar de os Jogos ambicionarem a paz e proporcionarem diversos exemplos de laços de amizade entre atletas, eles não provam um crescimento da compreensão entre as nações do mundo (e nem provam o contrário).

HARGREAVES (1992) demonstra a contradição entre a idéia inicial de congregar um maior número de países ao se realizar as competições olímpicas em diferentes lugares e a recente utilização dos Jogos por parte dos países como forma de legitimação de algum propósito.

Já TAKÁCS (1992), destaca a diferença entre o conhecimento dos preceitos olímpicos e a aplicação dos mesmos na prática. Uma vez que determinado atleta pode saber o que deve ser feito mas não agir dessa forma, ou até agir contrariamente.

Como o mesmo autor afirma que o ideal Olímpico é tão contraditório que quase tudo pode ser falado sobre ele, paro por aqui os exemplos de contradições. 
Antes de concluir sobre o Olimpismo nos dias atuais, gostaria de acrescentar alguns dos conceitos expostos por HALL (2001) em seu trabalho intitulado "A Identidade cultural na pós modernidade". Segundo essa tese, as velhas identidades que davam sustentação ao indivíduo no mundo social estão em declínio, fragmentando-o e retirando sua segurança com relação às suas origens e posição na sociedade. Como conseqüência da globalização por exemplo, é citado o declínio das identidades antigas e o surgimento de novas e híbridas identidades. Trazendo de volta para o Movimento Olímpico, essa hibridez pode estar constituída numa junção entre os fatores nacionais e comerciais, deixando os ideais iniciais cada vez mais distantes.

Concluo então com as idéias de ESPY (1988), que servem também aos propósitos de um estudo evolucionista de Charles Darwin. Segundo ele, o COI, como muitas outras organizações, tem como objetivo principal manter-se vivo, o que deixa os indivíduos, sejam atletas ou agentes, em posição secundária.

\subsection{O JORNAL COMO FONTE}

A maior parte da pesquisa realizada foi feita através de jornais, sendo assim, faz-se mister algumas palavras sobre o uso dessa fonte como pesquisa acadêmica.

De acordo com CAPELATO (1994), o jornal - antes considerado fonte suspeita e de pouca importância e hoje reconhecido como material de pesquisa valioso para o estudo de uma época - possibilita ao historiador acompanhar o percurso dos homens através dos tempos.

Para FERREIRA (1993), os jornais constituem uma fonte primária fundamental para as pesquisas dos historiadores e cientistas sociais. 
Entretanto, para compreender a participação de um jornal na historia, o pesquisador deve fazer indagações sobre seus proprietários, seus objetivos e recursos e também a quem ele se dirige. (RODRIGUES et alli, 1970).

Para CAPELATO (1994), houve uma modificação com relação à aceitação do jornal como fonte de estudos, fruto de uma reflexão sobre os problemas, abordagens e objetos da história.

De acordo com essa corrente, o passado - objeto do historiador - é construído e reconstruído com base nas necessidades e perspectivas do presente. Assim, compete ao historiador fazer reviver as personagens do passado, procurando entendê-las na sua época.

O historiador de hoje não reconhece os fatos como base da objetividade, pois reconhece que eles são fabricados e não dados. E que mais importante do que a realidade dos fatos em si, é o modo pelo qual os sujeitos da história tomaram consciência deles e os relataram.

Pela historiografia tradicional, o pesquisador deve verificar se o documento é falso ou verdadeiro antes de se basear nele. Segundo a nova historiografia, se entende que o documento falso é tão importante quanto o verdadeiro, implicando em se averiguar o porque de sua produção. Não há documento-verdade.

O jornal, ou o documento, não pode ser estudado isoladamente, mas relacionado com outras fontes que ampliem sua compreensão. 


\subsubsection{O JORNAL DO BRASIL}

Um dos periódicos mais utilizados na pesquisa é o Jornal do Brasil. Compreendendo sua história, pode-se compreender melhor as informações nele contidas e aqui utilizadas como fonte de informação.

Fundado em 1891 por Rodolfo Souza Dantas e Joaquim Nabuco, o matutino carioca nasceu no centro de acirrados debates políticos reunindo intelectuais de grande relevância no país, que questionavam o regime republicano recém instalado (SODRÉ, 1966).

Em sua declaração de princípios, o Jornal do Brasil afirmava seu propósito de criticar o governo estabelecendo limites a essa atuação.

Em 1893, sob nova direção, entregue a Rui Barbosa, o jornal se define defensor do regime republicano, associado ao combate da ditadura de Floriano Peixoto através da valorização da Constituição.

Por combater o regime vigente o jornal é vítima de uma invasão e destruição que obriga a sua venda.

Em seu retorno em 1894, sob a direção de Fernando e Cândido Mendes de Almeida, afirma seu propósito de assegurar aos poderes públicos seu apoio, sempre que necessário para sustentar a autoridade legal. Paralelamente propunha-se ainda a ser um órgão de imprensa popular, defensor dos pobres e oprimidos e divulgador de suas queixas e reclamações. Abandonando assim os inflamados debates políticos. Durante essa fase, o periódico caracterizou-se como um órgão informativo muito mais do que de opinião (FERREIRA, 1993). 
Com a primeira guerra e o encarecimento do papel o jornal foi hipotecado ao conde Ernesto Pereira Carneiro, que buscou reconquistar o prestígio do período inicial com moderação e prudência a fim de se evitar novos riscos para o jornal.

Mesmo com a prudência o jornal foi impedido de circular após a revolução de 1930 . Para a volta a circulação substitui-se um redator comprometido com o regime deposto por um com boas relações com o governo revolucionário.

A cautela na impediu o jornal de se engajar na campanha pela constitucionalização e apoio à constituição.

$\mathrm{Na}$ organização interna o jornal ainda enfrentava problemas financeiros que o obrigaram incluir anúncios, deixando de lado as preocupações pelos temas políticos e abandonando o interesse pelas artes e literatura.

Na década de 1950 o jornal passa por uma reforma de sucesso que volta a introduzi-lo entre os grandes jornais do período (FERREIRA, 1993), destinando-se a um público de elite (CAPELATO, 1994).

\section{RESULTADOS E DISCUSSÃO}

\subsection{A FORMAÇÃO DO COMITÊ OLÍMPICO NACIONAL}

As primeiras informações obtidas, sobre a formação do Comitê Olímpico Nacional no JB divergem dos dados apresentados por FRANCESCHI NETO (1999). De acordo com o jornal, a idéia da formação de uma entidade nacional representativa se inicia no final de 1912.

Com o fim daquele ano, o próprio JB lança uma campanha em comemoração à abertura da temporada esportiva do ano de 1913, o ponto alto das celebrações seria a 
realização dos Jogos Olímpicos no Rio de Janeiro. Juntamente com o lançamento da idéia, o periódico fornece a proposta de formulação e organização dos Jogos Olímpicos na Capital Federal.

É interessante notar que os Jogos Olímpicos que se buscava realizar não eram os jogos internacionais quadrienais mundiais, mas o fato de utilizar o mesmo nome já indica a presença do ideal de Coubertin no Brasil.

A proposta se baseava no uso da competição para desenvolvimento físico da sociedade brasileira e desenvolvimento dos clubes esportivos. Para o diário, a pratica esportiva visava o aperfeiçoamento das raças, a robustez da espécie, preparando gerações sadias e fortes; E proporcionava um engrandecimento da nacionalidade, uma vez que a debilidade orgânica acarretaria a debilidade intelectual.

A organização ficaria a cargo das entidades esportivas e a idéia tinha como base um concurso realizado anteriormente com mais de cem clubes da capital e de Niterói, contabilizando mais de 6000 filiados, além dos alunos que adotam o nome dos institutos de ensino. O passo seguinte seria a participação de entidades de outros estados da federação.

As modalidades sugeridas eram concursos hípicos, tiro, remo, natação, esportes atléticos, ginástica, futebol, ciclismo, luta, esgrima, tênis e pentatlo moderno.

O comitê organizador, denominado de Comitê Geral, indicado pela reportagem seria composto de quatro presidentes das sociedades que dirigiam os clubes de esporte. A eles cabe escolher os lugares das atividades e deliberar sobre todas as medidas de caráter geral; devem ainda escolher dois secretários e um tesoureiro. O Presidente da República e o Prefeito da Capital seriam presidentes de honra. Para cada modalidade seria escolhida uma comissão responsável pela organização e fiscalização da mesma e seus membros seriam escolhidos ou indicados pelo comitê geral. 
A história do Olimpismo, segundo o jornal, já havia sido publicada em um texto escrito pelo diretor do departamento de educação física da ACM, e textos já haviam sido publicados sobre os jogos de Estocolmo em 1912.

No início de 1913 reúne-se pela primeira vez um comitê de organização dos Jogos Olímpicos do Rio de Janeiro, a preocupação eminente eram as possibilidades de angariar fundos para custear os Jogos. O comitê era constituído pelos seguintes representantes: Raul de Carvalho, presidente do Centro de Cronistas Esportivos (CCE) e membro da Comissão de Concursos Hípicos (CCH); General Brilhante, presidente da Confederação de tiro brasileiro (CTB); Comandante Raul de Faria Ramos, presidente da Federação Brasileira das Sociedades do Remo (FBSR); Álvaro Zamith, presidente da Liga Metropolitana de Esportes Atléticos (LMEA); Arthur Maciel, secretário geral da ACM; e Almeida Brito, redator do JB.

A participação dos militares nesta comissão e em outras entidades esportivas confirma a presença desse grupo nas posições de destaque do cenário pós-republicano no Brasil, ressaltando sua importância no período.

Nas reuniões seguintes passou se a discutir também as necessidades financeiras acerca dos Jogos Olímpicos que seriam realizados em Berlim, no ano de 1916. É importante ressaltar que a formação desse comitê, em função da campanha que se iniciava, ainda era mais abrangente do que restritiva, buscando abarcar a maior quantidade de entidades relacionadas ao esporte possível, e que, até a formação oficial em 1914, nenhum de seus integrantes se considerava membro de entidade relacionada ao Movimento Olímpico.

A importância do JB se faz maior ainda nessas reuniões e em sua divulgação, uma vez que, além da presença de um redator nas assembléias do comitê provisório, os referidos encontros se davam no gabinete do redator-chefe do periódico carioca. 
Merece destaque entre as publicações desse período no JB, o caráter recente e desprovido de carga da empreitada. Numa das edições, por ocasião da falta de quorum em uma das reuniões iniciais, escreveu-se que apesar da campanha, não havia responsabilidade assumida e que não seria vergonha recuar dizendo que o meio esportivo brasileiro ainda não estava em condições de efetuar tais feitos.

Em uma outra reportagem, quando da semana de organização efetiva do comitê responsável pelos jogos do Rio, o jornal fala sobre diversos assuntos relacionados às conseqüências dos trabalhos do grupo de homens do esporte.

"Nesse dia, que será memorável para o nosso país, poderemos então afirmar com segurança que a nossa cara pátria ficará em condições de fazer-se representar com vantagem nos próximos Jogos Olympicos internacionais que serão levados a feito em 1916 em Berlim.

E por ventura, não era tempo, de já cuidarmos de apresentar no estrangeiro, especimens do nosso povo, robustos e fortes, em condições de lutar pela vida e bem servir a pátria em caso de necessidade, dando mostras assim da energia de uma nação? Certamente que sim. A América do Sul esteve presente nas pessoas dos sportmen chilenos, argentinos e peruanos.

A nossa cara pátria ainda não existe no mundo para o CIO pois ainda não tem delegação sua no Brasil. Disso ainda não cuidaram as comissões de propaganda do nosso país no estrangeiro, esquecendo-se de que estas importantes provas nacionais de esporte se efetuam com o 
concurso das principais nações civilizadas.” (JB,02/03/1913 - Pág. 15).

É curioso observar no primeiro parágrafo do excerto, o nacionalismo e a necessidade/vontade de se mostrar ao mundo enquanto país, mote que vai de acordo com as correntes da época. O segundo parágrafo, além do nacionalismo, reforça a eminência da guerra declarando a capacidade de "bem servir a pátria em caso de necessidade" e o desejo de se equiparar às outras nações da América do Sul. No último parágrafo destaco a inexistência de delegação do COI no Brasil e da caracterização dos jogos como realizados com participação das nações civilizadas, ou seja, além do desejo de se firmar como nação, a idéia de participação nos jogos era benéfica por colocar o país na vanguarda do civilismo, o que vai de encontro aos argumentos de Coubertin para o ingresso de pessoas de diferentes nacionalidades no COI.

A participação do Jornal do Brasil, crescia cada vez mais no contexto esportivo. Na mesma data da reportagem transcrita acima, é publicado um texto informando que a LMEA aceitou o pedido do JB e o escolheu para órgão oficial do Comitê, aumentando ainda mais a importância do referido jornal como fonte de informações para esse trabalho.

A LMEA, que era a entidade responsável por diversas modalidades no estado do Rio de Janeiro, de acordo com a pesquisa, foi também indicada para liderar os trabalhos de implantação dos JO.

A partir das primeiras reuniões, e buscando a máxima ampliação, em uma outra convocação para criação do comitê provisório, foram convidadas, além das agremiações anteriores, o Aero Club do Brasil (AEB), o Automóvel Club do Brasil (ACB), e também jornais da então Capital Federal. Curiosamente, essa reunião não acontece novamente por falta de quorum. 
No final do mês de março de 1913, a LMEA recebe carta contendo o regulamento dos JO Portugueses.

Apesar do incentivo do estrangeiro, prevalece a dificuldade de se conciliar datas para a realização da reunião do chamado comitê provisório.

No inicio de maio, portanto com um mês de intervalo, em virtude da necessidade de se escolher um representante brasileiro para o Congresso Olímpico em Lausanne, convoca-se novamente uma reunião.

A presença do vice-presidente do Comitê Olímpico Português (COP) é o diferencial do encontro. Entre eles, além de representantes do CCS, LMEA, CCH, AEB e ACM, encontra-se também um redator do JB. O comparecimento do português se mostra extremamente importante, uma vez que, até então, todas as reuniões marcadas não ocorreram. Talvez, se não houvesse o representante luso, mais uma vez a reunião não ocorreria.

Merece especial atenção nessa assembléia, uma carta do Sr. Duarte Rodriguez, português ligado ao COP, sugerindo seu nome para representar o Brasil no congresso de Lausanne e afirmando estar incumbido de vir ao Brasil para constituir o Comitê Olímpico Brasileiro e solicitar seu reconhecimento oficial. A decisão dos presentes é de negar o pedido feito pelo fato daquele comitê não ter autoridade para deferir a solicitação. Conclui-se dessa reunião que circulares serão expedidas aos grêmios esportivos e entidades correlatas para convocá-los para a reunião de eleição do $\mathrm{COB}$ e preparação da semana olímpica brasileira.

No fim de junho ocorre outra reunião do Comitê provisório. Nesta lê-se nova carta recebida do Sr. Duarte Rodriguez replicando a carta em que lhe fora negado o direito de representar o Brasil. Segundo o lusitano, seu intuito era de ver o Brasil em Berlim ao lado de Portugal como duas raças irmãs. 
Do ponto de vista da colonização, e entendendo que esses fatos ocorrem apenas duas décadas depois da proclamação da república, pode-se entender a atitude como uma tentativa de manter a colônia sob os domínios da matriz ou como o apoio para que o país desses seus primeiros passos em representações internacionais.

A edição de 28 de setembro de 1913 cita uma crise na organização esportiva brasileira em função da ausência de uma entidade nacional, capaz de gerenciar as demais. Surge assim a idéia da Federação Brasileira de Sports (FBS). A reportagem afirma que a entidade sul americana já formada que mais se assemelha à estrutura brasileira é a do Chile.

De extrema importância nesse processo, pois é um dos fatores que desencadeia a crise esportiva da década de 1930 e que gera a re-fundação do COB, o texto cita que a LMEA desdobra-se em diversas sessões como a Liga Metropolitana de Foot-ball, Liga Brasileira de Lawn-tênis, Associação Nacional de Sports Athléticos, Liga Nacional de Cyclismo, Circulo Nacional de Esgrima e a Associação Gymnastica Brasileira. Além dessas, existem as já organizadas, e portanto fora da alçada da LMEA, a Federação Brasileira de Sociedades do Remo e a Sociedade de Tiro Brasileiro.

Assim, segundo ao texto, a criação da FBS e seu reconhecimento pelo governo, a tornaria a mais alta autoridade esportiva do país e a única a dirigir os esportes em todo o Brasil:

“... a concentração de poder necessário ao progresso dos sports e das grandes collectividades; cada uma com vida autônoma, mas obedecendo a uma direcção superior e geral.

A Federação Brasileira de Sports será reconhecida e protegida pelo Governo, para que cuide dos sports do paiz."

(JB, 28/09/1913. Pág. 16) 
O passo seguinte a essa organização é tido pelo jornal como a formação de um Conselho Sul-Americano de Sports, que culminaria na Nação Sul-Americana de Sports. Mais uma vez compartilhando da internacionalização em voga no período.

Em sua sugestão de criação da FBS, o JB sugere que se reúnam as entidades já formadas e as sub-sessões da LMEA, e escolham os representantes gerais e o conselho, responsável pelas respectivas modalidades, ressaltando que esse conselho não deve ser formado por representantes das associações coletivas, mas sim por representantes das modalidades. Essa forma de organização, tal qual ocorre atualmente, deposita o poder das modalidades nos representantes e deixa assim os responsáveis pela coletividade sem nenhum poder para realizar modificações.

A participação governamental na entidade como legitimadora, também terá grande influência na desestabilidade do esporte nas décadas seguintes. Complementando a análise dessa participação, nota-se que o modelo de gestão proposto diferia completamente do modelo olímpico que se pretende apolítico.

Em maio de 1914 o JB publica uma carta do recém empossado delegado do Brasil no COI, Raul do Rio Branco.

O documento data de abril daquele ano e é enviado ao Sr. Almeida Brito - redator do Jornal do Brasil - que é descrito pelo autor como uma das personalidades de destaque no mundo do esporte e do atletismo brasileiro. No texto Raul afirma que não o conhece pessoalmente mas que seu nome lhe foi indicado por intermédio do representante português no COI, uma vez que uma delegação olímpica daquele país esteve no Brasil no ano anterior.

O objetivo da carta era estimular a implantação do ideal olímpico, descrito pelo remetente como a grande obra de regeneração pela educação atlética das forças físicas e 
morais que estava se alastrando pelo mundo, que já havia produzido notáveis resultados em países adiantados, e que começava a produzir benéficas repercussões na América do Sul.

O ingresso do primeiro brasileiro no COI, conforme suas palavras, se deu no congresso olímpico de Lausanne, ocorrido em maio de 1913 - como vimos nessa época já havia a discussão sobre a criação do comitê no Brasil. O fato novo é que a entrada de Rio Branco, que acelerou o processo de instalação do $\mathrm{COB}$, pode ter sido uma obra do acaso. Segundo a carta por ocasião do congresso olímpico, todo o corpo diplomático de Berna foi convidado para as sessões públicas e festividades da cidade que distava duas horas de Berna.

No local, o Ministro Brasileiro encontrou antigos conhecidos, entre eles, o Barão de Coubertin, que ele conhecia dos terrenos do esporte e do atletismo.

Desse encontro, e sabendo os representantes portugueses dos esforços brasileiros no sentido de criar um Comitê Olímpico, Coubertin convida Rio Branco para a função de delegado do Brasil no COI. A surpresa do convite fez o idealizador dos Jogos informar-lhe de que sua presença não seria de nada estranha, uma vez que um terço dos delegados eram diplomatas de postos muito afastados uns dos outros e que todas as pequenas e grandes potências européias e as nações mais avançadas de outros continentes, como EUA e Japão, estavam representadas no seu comitê.

É interessante refletir sobre a relação entre as informações trazidas pela carta e o que já se passava no Brasil. Pode-se assim, levantar a hipótese de que se Rio Branco não estivesse em Berna, mas em Washington ou Berlim em 1913, o Brasil não teria representante no COI naquele momento. Sem o representante, teria dificuldades para obter o reconhecimento internacional. A maneira mais fácil seria através do Comitê Olímpico Português, podendo até ser um luso o primeiro representante brasileiro no COI. Uma segunda hipótese pode ser levantada sobre a postura do idealizador dos Jogos Modernos: tendo conhecimento da 
movimentação brasileira e vontade de expandir sua idéia, ele escolheria qualquer personalidade brasileira tomada ao acaso no exterior, mesmo que não a conhecesse.

O aceite de Raul do Rio Branco foi dado levando em consideração tanto a adesão à causa esporte, como um serviço a prestar à pátria no sentido da internacionalização do país.

Essa revelação do Brasil nos meios internacionais contemplava tanto os interesses nacionais quanto os interesses de olímpicos. Para um país recém formado, necessitando de afirmação no cenário internacional e que tinha sua economia baseada na exportação, as relações internacionais legitimavam seu posto e aumentavam os potenciais consumidores. Quanto ao ideal coubertaniano, a entrada do Brasil beneficiava a sua expansão.

O fato de Raul do Rio Branco ser filho do Barão do Rio Branco também é de grande relevância em função da importância da referida família no cenário internacional. Segundo LINS (1996), a história do Barão é repleta de casos de repercussão internacional, incluindo disputas com Argentina, Equador, Colômbia, Peru, Guiana, além da famosa disputa com a Bolívia pelo Acre. Essas ações eram sempre arbitradas por países americanos ou europeus e foram responsáveis pelos contornos do território brasileiro e pela divulgação do país no mundo.

Assim, para o Movimento Olímpico, a escolha de Raul do Rio Branco como delegado do Brasil no COI contemplava uma série de fatores que extrapolavam o fator esportivo. Por sua vez, para o Ministro brasileiro, a participação no COI vinha de encontro às aspirações estrangeiras praticadas por seu pai.

$\mathrm{Na}$ carta, após discorrer sob os benefícios da prática física pregados por seu progenitor, Raul descreve o que acredita serem as medidas a serem adotadas pelos brasileiros. Segundo ele seria difícil pelo fator tempo e, principalmente, econômico, enviar a delegação brasileira aos jogos de Berlim em 1916. 
Além dos fatores supra-citados, a forma de desenvolvimento da educação física no Brasil e o estímulo dado à prática esportiva, não proporcionavam um desenvolvimento que fosse capaz de produzir, em larga escala, atletas para uma representação nacional. Segundo CASTELANI FILHO (1988), o modelo de educação física na época era militar e higienista, pautado no método ginástico alemão e francês, e havia ainda o preconceito da prática feminina. Diferindo, assim, de um modelo esportivo e de preparação de atletas.

Sua sugestão era de reunir as organizações e entidades ligadas ao esporte para se fundar o COB, a fim de que o esporte brasileiro tivesse representação não só no estrangeiro, como também perante o governo brasileiro para obter apoio moral e talvez financeiro.

A idéia de contrair apoio financeiro do governo, sugerida por um recém membro de uma instituição que se diz apolítica é um tanto controversa. Se se pensar que é preciso conhecer quem financia a mídia, conforme BOURDIEU (1997), inclusive a que serve de base a esse trabalho, faz se mister entender que a participação governamental influencia as decisões e faz cair por terra a independência política de uma instituição. Tal fato se torna ainda mais interessante no final da carta quando ele lembra que o Movimento Olímpico aceita apenas amadores, o que significa que ele usa a carta para explicar uma das bases do Olimpismo mas vai contra outra. Talvez isso possa ser explicado pelo fato de o próprio Coubertin passar por cima dessa idéia para obter a expansão de sua criação.

Voltando à carta, Rio Branco afirma que o mesmo texto foi enviado a quase todas as pessoas indicadas pelos representantes olímpicos portugueses - lista que ele anexa à carta, mas que não foi publicada pelo jornal - e pede que lhe sejam enviados outros contatos de representações que queiram tomar a responsabilidade de tamanha e gloriosa empreitada. 
Assim, com o apoio do delegado Brasileiro no COI, em junho de 1914 funda-se o CON, e se organizam as bases da FBS, sem, entretanto, ocorrer a sua fundação, como erroneamente afirma o COB (2003).

A ata de fundação do Comitê Olímpico Nacional, publicada integralmente na edição de 10/06/1914 do JB, revela mais uma vez o importante papel do periódico no desenvolvimento do esporte brasileiro. Segundo a ata, a reunião de fundação do CON ocorreu na sede da LMEA, que se localizava no próprio prédio do JB. E entre os presentes encontravam-se os dois mantenedores e um redator do JB, G. de Almeida Brito, o qual foi o responsável por adaptar o estatuto do Comitê Português para a realidade brasileira, sendo, assim, aceito pela assembléia.

Da fundação concluiu-se que o CON deveria eleger para cada estado, dois delegados que provocariam a constituição de comitês regionais, que teriam para o CON o mesmo sistema de relações deste com o COI. Os delegados se reuniriam por ocasião dos jogos nacionais ou por convocações extraordinárias. Ficou decidido ainda que se escreveria às autoridades para informar o êxito obtido.

Entre os nomes que constituíram o CON, figurava o de Fernando Mendes de Almeida como um dos representantes do automobilismo, o de seu irmão Candido Mendes de Almeida, no turismo, e o do redator Almeida Brito nos esportes atléticos, todos eles eram ligados ao JB.

O destaque histórico desta assembléia não ficou, contudo, restrito à fundação e constituição do CON. Em virtude das influências das correntes internacionais e visando uma instituição que unificasse os esportes, buscava-se fundar também a FBS. Entre os motivos que embasavam seu surgimento, figurava também a necessidade de se assegurar os benefícios do esporte em detrimento das numerosas entidades que, protegidas por sua vaidade e pela importância local e aparente, negavam a adesão às organizações mais gerais, faltando ao 
pensamento dos esportes que, segundo Almeida Brito (que se pronunciava na reunião), só poderia ser o benefício do cidadão. Nesse sentido, o orador afirma ainda que:

"Não havendo uma direcção geral, cada uma das collectividades procurará em primeiro logar o seu progresso, deixando para segundo logar os sports que são o motivo único de sua existência” (JB, 10/06/1914. Pág. 12)

Afirmação que tem sua aplicação ainda nos dias de hoje e que remete à forma com que se desenvolviam as entidades esportivas no início do século XX.

O pré-estatuto da FBS foi proposto na reunião também pelo redator do JB, que antes de se estender sobre esse assunto ressaltou a importância de não se fundar a FBS no presente encontro em função de se encontrarem no meio do ano esportivo pois isso seria prejudicial ao esporte.

O documento inicial, que foi aprovado, previa 20 conselheiros escolhidos em assembléia, os quais elegeriam a direção e as comissões de esportes terrestres, esportes marítimos, esportes aéreos, comissão geral de sindicância, de informação, de redação e de diplomacia. No seu artigo $4^{\circ}$ o documento convocava para final de novembro a assembléia de instalação, eleição do conselho e respectiva posse da FBS.

No dia 11 de junho, portanto três dias após sua fundação, deu-se a primeira reunião do CON. O local da reunião foi a sede da LMEA, ou seja, o edifício do JB. O presidente eleito do Comitê era Fernando Mendes de Almeida, proprietário do periódico carioca.

Na mesma reunião decidiu-se quem seriam os delegados brasileiros escolhidos pelo CON para representar o país no congresso olímpico de Paris, que aconteceria naquele ano. 
Aquele comitê em si, escolheu apenas o Sr. Ernani Pinto, que era representante do automobilismo no grupo e que estava em Paris. Outros dois brasileiros comporiam os representantes, ambos foram indicados por Raul do Rio Branco em sua carta: um era seu irmão, Paulo do Rio Branco, jogador de Rugby; e o outro era um amigo que morava em Paris, Alberto Klingelhofer, filho de um vice-cônsul e também jogador de Ruby.

Deixando de lado o fato de o rugby ter pouca adesão entre os brasileiros da época, é importante ressaltar que esse tipo de atitude reproduzia o modo como Coubertin incluía delegados no COI, e também mantinha os cargos sempre nos mesmo círculos sociais, como uma ação entre amigos.

Além do presidente Fernando Mendes de Almeida, o CON era constituído por Álvaro Zamith, primeiro vice-presidente; Capitão Ariovisto de Almeida Rego, segundo vice presidente; Almeida Brito, secretário nacional; Antonio de Oliveira Castro, secretário internacional; Pinheiro Barbosa, secretário de atas e Raul de Carvalho, tesoureiro.

\subsection{DECADÊNCIA E TRANSIÇÃO}

Sobre o período compreendido entre 1914 e 1935, os esclarecimentos foram insuficientes diante do grande material a ser pesquisado. Entretanto, algumas informações descobertas servem para elucidar alguns fatos e trilhar o caminho inicial que levará à busca de informações de extrema importância para a história das entidades esportivas brasileiras.

De acordo com as atas do Club Atlético Paulistano (CAP), em julho de 1925, após viagem à Europa com sua equipe de futebol, Antonio Prado Junior nomeia Raul do Rio Branco como sócio honorário pela contribuição do mesmo para o bom êxito da viagem. 
Pela mesma fonte, em fevereiro de 1926, Arnaldo Guinle é nomeado sócio honorário em atenção aos méritos pessoais dele, como esportista e como prova de alta estima do CAP pela Federação de Futebol Carioca. Tal fato nega a hipótese apresentada anteriormente de que de Prado Jr. e Guinle estreitaram laços após a administração do primeiro na Capital Federal, mas já demonstra a existência da entidade especializada de futebol.

O estudo mais aprofundado dos jogos do centenário, realizados em 1922 com o apoio e aprovação do COI, poderia trazer informações complementares sobre se houve a efetiva participação do CON na sua organização, ou se já nesse período as atribuições olímpicas ficavam a cargo da CBD.

\subsection{A FORMAÇÃO DO COMITÊ OLÍMPICO BRASILEIRO}

Apesar de 1935 ter sido o ano de fundação do COB, substituindo assim o CON fundado 21 anos antes, a formação da referida instituição tem suas raízes atreladas a um passado que pode datar de antes da formação da primeira entidade olímpica oficial do Brasil em 1914.

Segundo os jornais pesquisados, a instituição do $\mathrm{COB}$ se deu num momento turbulento do esporte brasileiro, em decorrência, principalmente, da profissionalização no futebol.

Um outro fator de grande relevância nesse momento é a participação do governo na criação de leis relativas ao esporte. Segundo MANHÃES (1986), todas as medidas definidoras de política no campo do esporte, foram originárias do Estado Novo. O conflito no esporte serve de pretexto para a criação de leis que o regulamentam. 
Além do profissionalismo, a forma de gestão esportiva também foi um fator de conflito entre as entidades esportivas. Como se percebe de sua denominação, a LMEA, a APEA e a CBD eram entidades não de uma modalidade exclusivamente, mas de várias. Assim, com o aumento do número de federações destinadas a uma única modalidade, surgem também as dissidências sobre a representatividade de cada uma delas.

Em outubro de 1934 o JB divulga a tentativa de se criarem federações de modalidades especificas. Em primeiro de janeiro de 1935 a CBD é acusada pelos homens ligados às federações de não querer a chamada pacificação entre as entidades. O JB, visivelmente favorável à CBD, explica que o que a entidade não concorda é com a criação dessas entidades especializadas, uma vez que com exceção do futebol, não se acreditava que nenhuma outra modalidade poderia manter uma federação com caráter nacional independente.

A crítica das entidades coletivas residia no fato de as mesmas não possuírem entidades cadastradas nos seus quadros e de criarem entidades fantasmas para dar corpo à sua instituição.

Faz se importante ressaltar que o sistema de organização voltado para todas as modalidades, reproduzia a forma de organização dos clubes, uma vez que os mesmos gerenciavam as modalidades de seu quadro como um todo, relacionando-as com outros clubes, e não individualmente, e que a forma de organização baseada nas modalidades não era uma novidade, visto que a formação do CON de 1914 já contava com entidades nacionais representativas de uma modalidade, como a Federação Brasileira das Sociedades do Remo.

Segundo um documento do acervo do CAP, a Liga Paulista de Futebol, que em 1915 se tornou a Federação Brasileira de Futebol, foi fundada em 1901 e em 1914 já possuía as instruções de um dos fundadores da FIFA para se inscrever na entidade. O mesmo documento 
alega que as relações sul-americanas no futebol se iniciaram com a Liga Paulista de Futebol, uma entidade especializada.

Desse modo, enfrentando todas essas dificuldades, o esporte caminhava.

O passo seguinte, que contribuiu para aumentar ainda mais a crise esportiva brasileira foi dado em 20 de maio de 1935. Sob a alegação de se fundar na forma das leis olímpicas e em obediência a elas, foi fundado o COB pelos delegados brasileiros no COI. A justificativa dessa empreitada se baseava no fato de a CBD, entidade responsável pelas relações esportivas internacionais e encarregada também pela participação do Brasil nos Jogos Olímpicos, não ser credenciada pelos estatutos olímpicos.

A assembléia ocorreu no prédio da Federação Brasileira de Futebol, e contou com a presença de representantes das federações brasileiras de atletismo, basquete, remo, natação, tênis, vela e motor e ciclismo, e foi regida por dois dos três membros brasileiros do COI: Arnaldo Guinle e José Ferreira dos Santos.

A CBD, buscando evitar a perda dessa função olímpica, funda no dia 2 de junho o seu COB. Nesta reunião, pesava a seu favor a participação de entidades do governo brasileiro.

O motivo da discórdia com relação à fundação dos COB - não bastasse os problemas anteriores - estava relacionado principalmente ao artigo 17 dos estatutos do COI, que explica que os membros do COI devem em um primeiro momento fundar um Comitê Olímpico Nacional em acordo com as federações e sociedades nacionais pois, somente o Comitê tem autoridade para transmitir ao COI os despachos enviados pelas federações nacionais que caracterizam a participação nos JO. Ao que parece, mas que não é possível concluir, ou a inscrição brasileira nos jogos até então era feita diretamente pela pessoa de um dos delegados brasileiros, ou o Comitê Internacional as aceitava sem cumprir seu estatuto. 
Uma matéria publicada no Jornal dos Sports de 9 de junho de 1935, explicando os desentendimentos entre os comitês, conclui que nenhum deles é legitimamente legal pois o primeiro a ser fundado não foi criado em acordo com as federações nacionais, apenas convidaram-nas a participar. O segundo é considerado ainda mais ilegal por não possuir delegados olímpicos.

O arbítrio da situação fica a cargo do COI. Cartas e telegramas são enviados. A CBD se baseia no apoio do governo e na força das federações a ela subordinadas. Os delegados se utilizam de sua posição hierárquica.

Em 26 de junho o COI reconhece oficialmente o COB de seus membros.

A decisão do Comitê Internacional ressalta o poder dos delegados brasileiros e também tenta destacar o seu caráter apolítico.

\section{CONSIDERAÇÕES FINAIS}

A dificuldade da realização de uma pesquisa histórica no Brasil faz com que seu exemplo seja citado nessas considerações a fim de estimular o acesso e a compreensão da importância da história e de seu estudo para a sociedade.

Os objetivos iniciais propostos foram parcialmente atingidos, uma vez que o trabalho indica, mas não permite afirmar com exatidão, que, em função da proximidade entre a FBS e o CON, houve por parte da CBD (antiga FBS) uma apropriação das funções olímpicas. Sendo assim, a fundação do COB em 1935 foi decorrência da inexistência real do CON fundado em 1914.

Pode-se concluir com confiança que os comitês fundados em 1935 tinham a mesma função, mas diferiam completamente daquele fundado 21 anos antes. 
Em 1914, a fundação do comitê buscava assentar o nome do Brasil no exterior, caracterizando uma fase de internacionalização e reconhecimento do país. A forma de organização das entidades reproduzia o modelo liberal dos estados brasileiros após a proclamação da república. Além disso, a busca por entidades para compor o CON demonstrava uma comissão aberta à participação de qualquer pessoa ou entidade ligada ao esporte.

Já em 1935, o Brasil já se achava mais presente no cenário internacional. A ditadura de Getulio Vargas no período do Estado Novo regulamentava as entidades esportivas e daí a necessidade de se aproveitar e regularizar a ausência, pelo menos na prática, de um COB. Por último, a disputa por representação na década de 1930 torna a fundação do comitê um ato restrito, em que todos são convidados mas poucos podem participar efetivamente.

A inexistência de reuniões por falta de pessoas, em 1913, e a não exigência de obtenção de êxito demonstra a pouca preocupação com relação ao tempo, situação completamente diferente da organização de 1935. Nesta ocasião, a falta de quorum poderia representar a perda do pioneirismo.

A relação das entidades especializadas com as entidades coletivas na década de 1930 era muito mais delicada do que a mesma relação nos anos anteriores.

Em comum os três comitês demonstram a característica evidenciada por HOBSBAWM (1988) de serem entidades compostas por pessoas de mesma classe social.

Outros fatores merecem destaque. A participação militar não se restringia ao ambiente político, se fazendo muito forte também no ambiente esportivo - a primeira medalha brasileira em JO foi obtida por um componente das forças armadas - e influenciando pesadamente o desenvolvimento da educação física brasileira. 
O desejo de pertencer ao grupo de nações civilizadas dos brasileiros do início do século corrobora a idéia de ELIAS (1992) de que o processo civilizador facilitou, não tanto a expansão mas principalmente, a aceitação das normas de conduta inglesas pelos países que a conheceram.

A participação do Jornal do Brasil na fundação do CON é de grande importância, demonstrando a proximidade da relação entre as instituições esportivas e esse meio de comunicação, expressando assim a validade dos dados por eles divulgados. Pelos documentos apurados, além da participação nas reuniões de formação do comitê dos dois mantenedores e de um redator do jornal, que foi o responsável pela criação dos estatutos aprovados, a sede do jornal era o local dos encontros e o periódico era o órgão oficial de divulgação da LMEA, a entidade responsável pela organização do CON.

A participação portuguesa no ingresso do Brasil no Movimento Olímpico também merece destaque, pois até mesmo a carta de Raul do Rio Branco, que acelerou o processo de criação do CON, não seria possível sem a indicação de nomes para que fossem endereçadas as correspondências. Ademais, não fosse a presença do vice-presidente do Comitê Português e o estatuto da instituição trazido por ele, os brasileiros teriam dificuldade em encontrar modelos para se inspirar, ou teriam de aguardar algum modelo enviado por Rio Branco. Pesa ainda a favor dos representantes lusitanos as informações por eles prestadas a Pierre de Coubertin que o informaram sobre a movimentação brasileira pró-Olimpismo. Sem elas o convite para o ingresso do Brasil poderia ter demorado muito mais.

Voltando à proposta de descobrir o passado para compreender o presente e melhorar o futuro, pode-se agora fazer afirmações sobre o que se espera sobre o esporte.

Da formação do esporte moderno, pode-se aproveitar a idéia inicial de Arnold e deixar que ele seja dirigido pelos próprios atletas, não exclusivamente, mas uma maior participação 
dos atletas pode contribuir e muito para a solução de problemas dentro das ligas esportivas, respeitando suas limitações e ouvindo suas opiniões.

Sobre o Comitê Olímpico Internacional, a história de vida de Coubertin mostra as razões de sua instituição ter as bases que tem. A guerra, a descrença política, a educação como meio de sucesso e a influência inglesa estão na base de seu movimento. Entretanto a influência política inglesa, que o fez optar pelo amadorismo, demonstrou que para obter o sucesso de sua empreitada e divulgar seu movimento, algumas concessões precisariam ser feitas. A discrepância entre a realidade e as bases de seus ideais confirmou a necessidade das concessões obrigando-o a colocar de lado alguns de seus princípios. Com esses princípios já não mais tão fortes, outras instituições ao redor do globo perceberam a falibilidade da idéia de Coubertin e aproveitaram para incluir os seus interesses.

É necessário enfatizar que não cabe um julgamento de valor sobre os interesses dos países que contribuíram para essa dissidência, uma vez que cada um, obviamente, usaria a falha conceitual para obter benefícios próprios, preferencialmente no campo esportivo. $\mathrm{O}$ importante é que com tantas idéias, o mundo olímpico se tornou controverso, sofre dessa conseqüência e, a não ser que ocorra uma reformulação de peso, continuará a sofrer desse mal, principalmente porque a cada dia novas situações e idéias aparecem no bojo de seus conceitos.

Para finalizar, pode-se considerar a história social olímpica brasileira como um quebracabeça que já tem grande parte de suas peças encaixadas mas que ainda não está completo. Um estudo aprofundado sobre os jogos de 1922 realizados no Brasil e uma pesquisa sobre as influências das modalidades e principalmente do futebol, nas resoluções esportivas brasileiras do início do século XX completariam esse quadro com brilhantismo. 
BARBANTI, V.J. Dicionário de educação física e esporte. Barueri: Manole, 2003.

BETTI, M. Educação física e sociedade. São Paulo: Movimento, 1991.

BOUDON, R. \& BOURRICAUD, F. Dicionário crítico de sociologia. São Paulo: Ática, 1993.

BOURDIEU, P. Coisas Ditas. São Paulo: Ed. Brasiliense, 1991.

BOURDIEU, P. Sobre a Televisão. Rio de Janeiro: Jorge Zahar Editor, 1997.

BRACHT, V. Sociologia Crítica do Esporte: Uma Introdução. Vitória: UFES, Centro de Educação Física e Desportos, 1997.

BROHM, J. M. Sociología política del deporte. México: Fondo de Cultura Económica, 1982.

CAPELATO, M. H. R. Imprensa e História do Brasil. São Paulo: Contexto/EDUSP, 2a ed. 1994.

CARDOSO, C.F.S. \& BRIGNOLI, P. Os métodos da história: introdução aos problemas, métodos e técnicas da história demográfica, econômica e social. Rio de Janeiro: Graal, 1990.

CARTA OLÍMPICA. Lausanne: Comitê Olímpico Internacional. 2001

CAStellani FilHO, L. Educação Física no Brasil: Uma História que Não se Conta. Campinas: Papirus, 1998.

COMITÊ OLİMPICO BRASILEIRO. O Comitê Olímpico Brasileiro. Rio de Janeiro. 2003.

DUNNING, E. Sport in Space and Time: "Civilizing Processes", Trajectories of StateFormation and the Development of Modern Sport. International Review for the Sociology of Sport. V. 29, n. 04, p.331-347, 1994. 
DUNNING, E. Civilização, formação do Estado e primeiro desenvolvimento do esporte moderno. In: GARRIGOU, A. \& LACROIX, B. (Orgs.) Norbert Elias: A política e a história. São Paulo: Ed. Perspectiva, 2001.

ELIAS, N. Introdução à Sociologia. Lisboa: Edições 70, 1980.

ELIAS, N. Introducción. In: ELIAS, N \& DUNNING, E. Deporte y ocio en el proceso de la civilización. México: Fondo de Cultura Económica, 1992.

ESPY, R. The Olympic Games: Mirror of the world. In: SEGRAVE, J. \& CHU, D. (Eds.) The Olympic Games in Transition. Champaing: Human Kinetics, 1988.

FAUSTO, B. História do Brasil. São Paulo: Edusp, 1995.

FERREIRA, M. M. Imprensa e modernização dos anos 50: a reforma do Jornal do Brasil. Anuário Brasileiro de pesquisa em jornalismo. ํo2, p. 141 - 149, 1993.

FRANCESCHI NETO, M. A Participação do Brasil no Movimento Olímpico Internacional de 1896 a 1925. Dissertação de Mestrado. Programa de Pós-Graduação em Educação Física da Universidade Gama Filho. Rio de Janeiro, 1999.

FRANCO JR.,H. A Dança dos Deuses: Futebol, Sociedade e Cultura. São Paulo: Companhia das Letras, 2007.

GARRIGOU, A. O “Grande Jogo" da Sociedade. In: GARRIGOU, A. \& LACROIX, B. (Orgs.) Norbert Elias: A política e a história. São Paulo: Ed. Perspectiva, 2001. GONZÁLEZ, J.I.B. Introducción. In: BROHM, J. M.; BOURDIEU, P.; DUNNING, E. HARGREAVES, J.; TODD, T; YOUNG, K. Materiales de Sociología del Deporte. Madrid: Las ediciones de La Piqueta, 1993.

GUTTMANN, A. From ritual to Record: the nature of modern sports. New York: Columbia University Press, 1978.

HALL, S. A identidade cultural na pós-modernidade. Rio de Janeiro: DP\&A, 2001. 
HARGREAVES, J. Olympism and Nationalism: Some Preliminary Consideration.

International Revue for the Sociology of Sport. N. 27, p. 119 - 135, 1992.

HELAL, R, O que é sociologia do esporte. São Paulo: Editora Brasiliense, 1990.

HOBERMAN, J.M. Sport and Political Ideology. Austin: University of Texas Press, 1984.

HOBSBAWM, E. A Produção em Massa de Tradições: Europa, 1870 a 1914. In:

HOBSBAWM, E. \& RANGER, T. A Invenção das tradições. São Paulo: Paz e Terra, 1988.

HOBSBAWM, E. Era dos impérios: 1875- 1914. Rio de Janeiro: Paz e Terra, 1992.

HOBSBAWM, E. Era dos extremos: o breve Século XX, 1914 - 1991. São Paulo: Companhia das Letras, 1995.

HUIZINGA, J. Homo Ludens: o jogo como elemento da cultura. São Paulo: Editora Perspectiva, 1971.

JENNINGS, A. Carton Rouge. Paris : Presses de la Cité, 2006.

JENNINGS, A \& SIMSON, V. Os Senhores dos Anéis. São Paulo: Editora Best Seller, 1992.

LEMOS, D.L.R. A influência de Antonio Prado Junior e Arnaldo Guinle na fundação do COB: precedentes e procedentes. In: Anais do V Fórum Olímpico - Estudos Olímpicos: ética e compromisso social. São Paulo, 2004.

LICO, F. A. A. O Boicote aos Jogos Olímpicos de Moscou - 1980: Uma Análise da Reação do Movimento Olímpico Brasileiro e Internacional. (Mestrado em Educação Física), Universidade de São Paulo, São Paulo. 2007.

LICO, F. A. A. \& LEMOS, D. L. R. Implicações Ideológicas e Geopolíticas do Fenômeno Esportivo na Contemporaneidade. In: Rubio, K. Educação Olímpica e Responsabilidade Social. São Paulo: Casa do Psicólogo, 2007. 
LINS, A. Rio Branco (O Barão do Rio Branco) - Biografia pessoal e história política. São Paulo: Ed. Alfa-Omega, 1996.

MacALOON, J. J. This great symbol. Chicago: The University of Chicago Press, 1984.

MANDELL, R. D. Historia cultural del deporte. Barcelona: Bellaterra, 1986.

MANHÃES, E. D. Política de Esportes no Brasil. Rio de Janeiro: Graal, 1986.

McINTOSH, P. C. O Desporto na sociedade. Lisboa: Prelo, 1975.

MORFORD, R. Olympism: tattered remnant of a Victorian fancy. International Journal of Phisical Education. N²3, V. 01, p. 10-14. 1986.

RIBEIRO, R. O Caminho da Bola - 100 anos de história da FPF. Vol. 1:1902 - 1952. São Paulo: CNB, 2000.

RODRIGUES, J. H.; BAUER, W.; LACOMBE, A. J.; QUINTAS, A. A Imprensa como fonte histórica. Jornalismo, Série F., Publicação do departamento de Jornalismo e Editoração da ECA-USP, São Paulo, 1970.

RUBIO, K. O atleta e o mito do herói. São Paulo: Casa do Psicólogo, 2001.

RUBIO, K. Do Olimpo ao pós-olimpismo: Elementos para uma reflexão sobre o esporte atual. Revista Paulista de Educação Física. V.16, n. 02, 2002.

RUBIO, K. Medalhistas olímpicos brasileiros: memórias, histórias e imaginário. São Paulo: Casa do Psicólogo, 2006.

SAlVADOR, J. L. EI Deporte em occidente. Madrid: Historia, Cultura y Política. Cátedra, 2004.

SCHAFF, A. História e Verdade. São Paulo: Martins Fontes, 1991.

SEPPANEN, P. The Olympics: A Sociological Perspective. International Revue for the Sociology of Sport. N. 19, p. $113-127,1984$. 
SEVCENKO, N. A Corrida para o Século XXI: No Loop da Montanha Russa. São Paulo: Companhia das Letras, 2001.

SODRÉ, N. W. A História da imprensa no Brasil. Rio de Janeiro: Civilização Brasileira, 1966.

STRUNA, N. L. Pesquisa histórica em atividade física. In: THOMAS, J. R.; NELSON, J. N. Métodos de pesquisa em atividade física. Porto Alegre: Artmed, 2002.

TÁKACS, F. Ethos and Olympism: The Ethic Principle of Olympism. International Revue for the Sociology of Sport. N. 27, p. $223-233,1992$.

TAVARES, O. G. Esporte, Movimento Olímpico e democracia: O Atleta como Mediador. (Doutorado em Educação Física), Universidade Gama Filho, Rio de Janeiro. 2003.

TAVARES, O. G. Algumas reflexões para uma rediscussão do fair-play. In: TAVARES, O. \& DACOSTA, L.P. (eds) Estudos Olímpicos. Rio de Janeiro: Editora Gama Filho, 1999. VÁRIOS AUTORES. Coleção Anglo. São Paulo; Anglo, 1991.

ZAKUS, D. H. The International Olympic Committee: Tragedy, Farce and Hipocrisy. Sociology of Sport Journal. N. 09, Pág. 340 - 353, 1992. 